University of Louisville

ThinkIR: The University of Louisville's Institutional Repository

Electronic Theses and Dissertations

$5-1943$

\title{
A study of twenty-eight working mothers and their problems.
}

Marianna E. Lawson

University of Louisville

Follow this and additional works at: https://ir.library.louisville.edu/etd

Part of the Social Welfare Commons

\section{Recommended Citation}

Lawson, Marianna E., "A study of twenty-eight working mothers and their problems." (1943). Electronic Theses and Dissertations. Paper 1990.

https://doi.org/10.18297/etd/1990

This Master's Thesis is brought to you for free and open access by ThinkIR: The University of Louisville's Institutional Repository. It has been accepted for inclusion in Electronic Theses and Dissertations by an authorized administrator of ThinkIR: The University of Louisville's Institutional Repository. This title appears here courtesy of the author, who has retained all other copyrights. For more information, please contact thinkir@louisville.edu. 
UNIVERSITY OF LOUISVILLE

A STUDY OF TWENTY-EIGHT WORKING

MOTHERS AND THEIR PROBLIMS

\author{
A Dissertation \\ Submitted to the Faculty \\ of the Graduate School of the University of Louisvilie \\ In Partial Fulfillment of the \\ Requirements for the Degree \\ of Master of Science in Social Administration \\ Division of Social Administration \\ By
}

Marianna E. Lawson

1943 
NAME OF STUDENT:

TITLA OF THESIS:
Marianna E. Lawson

A Study of Twenty-Eight Working Mothers and Their Problems

Approved by Reading Committee Composed of the Following Members:

John J. Cronin

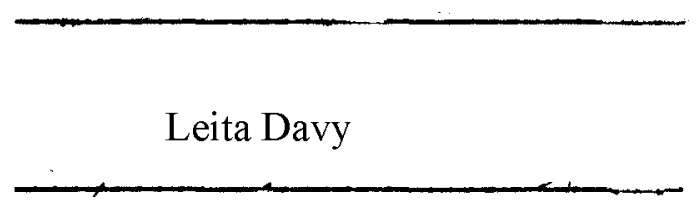

Gardner F. Cook

NAME OF DIRECTOR: MR. JOHN J. CRONIN

Date: May 24, 1943 
For assistance with this thesis the writer wishes to express her appreoiation to many individuals. The writer wishes to acknowledge especially her gratitude to Mr. John J. Cronin for his kind assistance, encouragement, and personal guidance; to M1ss Esther Taylor for suggestions and for her kindness in placing the case records and other material of the Family Service Organization at her disposal; to Drs. Rubado and Hess of The Louisville Board of Education for permission to secure and use records from the Louisville Public Schools; to Miss Mary Logan Cline for her encouragement and assistance; and to other members of the Family Service Organization staff for their helpfulness. 
A STUDY OF TWENTY-EIGET WORKING MOTHARS AND THEIR PROBLEMS 


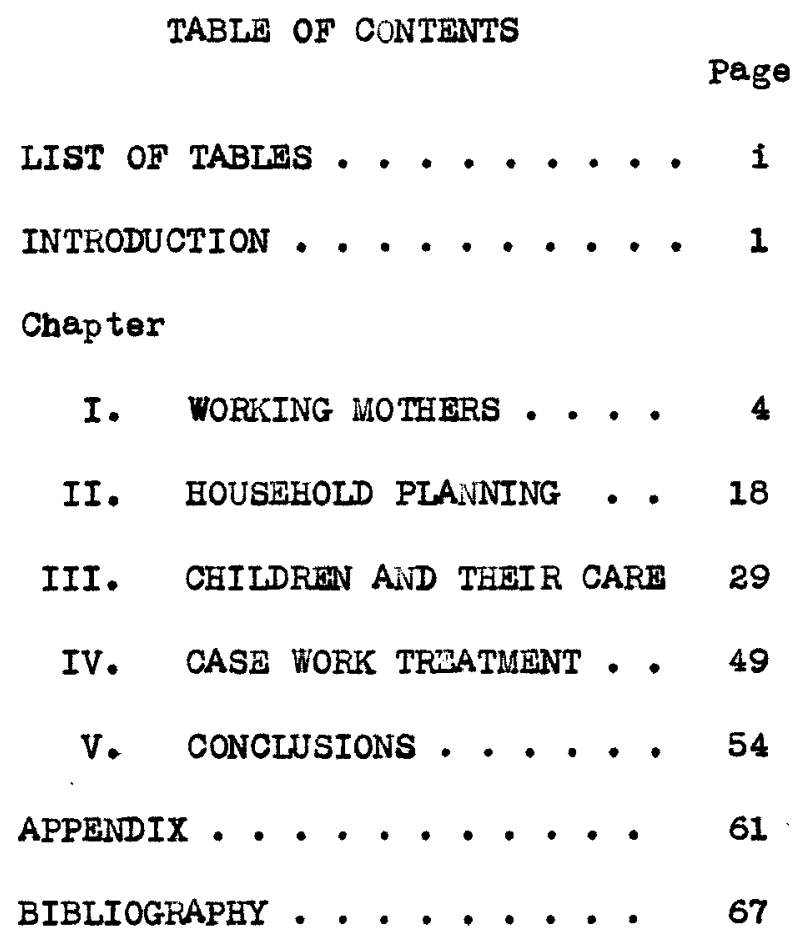


1. Marital Status of Mother . . . . . . . 6

2. Number of Relatives in Home According to Age of

Mother ......................7

3. Reason for Mother Working According to Marital

Status of Mother ................. 7

4. Marital Status of Mother According to Length of

Employment after Marriage . . . . . . . . 8

5. Marital Status of Mother According to Earnings of

Mother .................... 9

6. Weekly tearnings of Married Couples......... 9

7. Weekly Earnings of Separated Couples... . . . 10

8. Weekly earnings of Divorced Couples . . . . . . 11

9. Weekly Earnings of Mother According to Grade

Completed .................... 11

10. Weekly Earnings of Mother According to Occupational

Status................... 12

11. Occupational Status of Mother According to Length

of Present Imployment............. 13

12. Occupational Status of Mother According to Time Lost

During October, 1942 .............. 13

13. Number of Days' Employment Lost by Mother According

to occupational Status . . . . . . . . . . 14

14. Weekly Contributions of Other Adults Living with

Femily .................... 15

15. Wage Rarners including Mother According to Number

in Household . . . . . . . . . . . . 15

16. Performance of Household Tasks According to Hember

of Household \& Race . . . . . . . . . . . 21

17. Time Needed for Various Tasks According to U. S.

Bureau of Home Economics, New York Survey \&

Approximate Amount Spent by Working Mothers ... 
18. Number of Children According to Age Groups . . . 29

19. Earnings of Ch1ldren ........... 30

20. Type of Care of Children According to Ages of

Children .................. 32

21. Marital Status of Mother According to Ages of

Children .............. 34

22. Total \& Average Number of Children According to

Marital Status of Mother . . . . . . . . 35

23. Type of care of Children According to Number of

Children .............. 36

24. Type of care of Children According to Age of

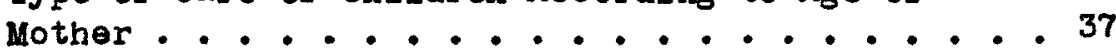

25. Type of care of Children According to Weekly

Earnings of Mother.............. 39

26. Type of care of Children According to Weekly

Cost of Care................ 40

27. Week $1 \mathrm{y}$ cost of care of Children According to

Weekly Earnings of Mother........... 41

28. Number \& Ages of Children According to Age of

Relative Caring for Them .......... 42

29. Number of Years School ketardation According

to Race.............. 44

30. Scholarship of Children .......... . 45

31. Number of Days Absence from School . . . . . 45

32. Problems of Chlidren ........... . 46

33. Casework Treatment of Working Hothers under the

care of Family Service Organization of

Louisville, Kentucky ........... . 50 
INTRODUCTION 
Introduction

What are the problems of working mothers was the question that was uppermost in our minds when we began our study of twenty-eight working mothers and their families. We relt that through examining data regarding ages, occupation, education, marital status, number of dependents, et cetere that we would be able to ascertain at once some of the difficulties these mothers were facing. We wanted to know how wuch of the financial burden the mother carried and whether she was showing any signs of strain because of her double duties of wage earner and housekeeper. What help did she have from other members of the family? How much time was necessary to perform the household tasks? What was left undone? What kind of care was she able to arrange for the children and was it adequate?

We also wanted to Iearn something of the problems about which these mothers were worrying and whether or not they were connected with their employment. What did the casework consist of and was the mother satisfied with the plan made? Were community resources adequate? Was there further service that could be rendered to the client?

We selected all of the mothers who were regularly employed on November 1, 1942 and who were under the care of a caseworker of the Family Service Organization of Louisville, Kentucky. A larger universe was considered but it was decided to make a more intensive study of a smaller number of families. This group (thirty families) was part of the major care caseload of Family Service Organization. The total major care caseload was 161 on November 1, 1942. Major care families are those 
families where a continuing plan of cesework service is offered the client. This major care is distinguished from the other classiflcation, minor care, usually by the length of time the client is known to the agency. Minor care as the name implies is for a shorter period of time whereas major care usually involves cllent and caseworker working together over a longer period of time.

The original plan was to read the case records, interview the mothers, and 1111 out a schedule with data from both sources. 1 This plan was carried out but we were unable to locate two of the mothers and our universe was reduced from thirty to twenty-eight. Interviews were conducted in the client's home after a letter making an appointment had been written by the caseworker.

After this part of the study was completed, it was decided to secure additional information about these families by securing records from the school on attendance, scholarship, and behavior. 2 This was secured for the most part from the principel of the school although in a few instances the material wes supplied by the clerk. Permission for the use of the meterial was secured from the Board of Bducation of the Loulsville Public Schools. It was not possible to secure this material on all of the school chllaren because of some famflies' feeling about anyone knowing of their contact with the Family Service Organlzation. For that reason, sohool material is included on only thirty-six of the Iifty school children.

After these steps were taken, the materiel or data secured were

1 See Appendix, p. 61 for copy of the schedule

2See Appendix, p. 65 for copy of sohedule for sohool information 
tabulated, analyzed, and conclusions were drawn. For comparative purposes, material was secured from the United States Women's Bureau and the Bureau of Home Economics, United States Department of Agriculture. 
CEAPTER I

WORKING MOTHERS 
Chapter I

Working Mothers

Only those families who were under the supervision of a caseworker Prom Family Service Organization and in which the mothers were employed on November 1, 1942 were selected for study. There were thirty in the original group but because we were unable to interview two of the mothers, our study consists of twenty-elght working mothers and their ramilies. Elghteen are white and ten are negro. These mothers vary in age from twenty to fifty years and are employed in numerous types of work.

The health of the mothers as noted in the case records indicated that half had some sort of physical trouble. Two had serious difficulty, one bed eyesight and the other a gyneoologio condition. None of the mothers were diagnosed as suffering from mental 111ness. One, however, was very suspicious and was thought to have some paranold trends. Ten others manifested such symptoms as nervousness, tenseness, and insteb111ty.

These women work an average of 47.32 hours a week. The white women's hours are longer (50.06), probably because nine of them work overtime and one is a nurse on twenty hour duty. Rleven of the white women work on Saturday, thus working a $81 x$ day week. The Negro women work an average of 42.40 hours week and none work overtime. Only four work on Saturdays. However, the white women gein some in that eight of the nine who work overtime recelve additional pay for this work (usually time and one-half). 
The time required to go to and from work lengthens the working day. It requires on the average more than six hours a week so that the average time spent by the mother away from the home is 54.03 hours.

$$
\text { It will be shown below }{ }^{1} \text { that an average of thirty-two hours a }
$$

week is needed for the housework. The combination of working hours plus the time spent in doing the housework is eighty-six hours a week, an average of 12.29 hours per day seven days a week. Thus only 11.71 hours a day are left for sleeping, dressing, eating, recreation, and any other type of activity the mother pursues.

In addition to the time which the mother gives, there is also the money which she earns. All the mothers except two contribute their entire salary for family expenses. Of course, there are some expenses incident to her employment which must be met. The mothers' earnings vary from $\$ 4.00$ to $\$ 38.61$ a week. This data is tabulated according to type of work in Table 5. This compares favorably with information secured by the Women's Bureau.

The usual levels of women's earnings are indicated by a general survey of the more recent material available from various sources, which shows that, in these five major occupation groups, women's median or average earnings range about as follows: Domestic and personal service: Homes (cash wage), $\$ 5.79$ to $\$ 14.65$ a week Hotels and restaurants, $\$ 5.75$ to $\$ 16.25$ a week..... Clerical occupations: $\$ 26.15$ (clerks) to $\$ 28.65$ (seoretaries) a week..... Manufacturing: Recent figures for various industries, $\$ 12.46$ to $\$ 20.20$

Professional service: Trained nurses, $\$ 1,620$ to $\$ 2,300$ a year, the minimum and maximum civil service entrance salaries.

Sales occupations:

12. a week in limited-price stores to $\$ 13_{2} 85$ a weok for regular workers in department stores.

${ }^{1}$ See Chapter II, p.

${ }^{2}$ U.S.Dep't of Labor, Women's Bureau Bulletin No. 155, Women in the Economy of the United States of Americe, (Washington: Government Printing Office, 1937) p. 48-49 
Many of these workers have been working for years. Only seven were not employed prior to marriage. We notice that twenty-two were $10 s 8$ than twenty when they started working. This certainly is reflected in the lack of education of these women. Only one has a high school education, nineteen have an eighth grade education but less than a twelfth grade, and eight have not completed the elghth grade.

This material regarding the age at which the mother began work does not entirely agree with that found by the Nomen's Bureau, United States Department of Labor, in their survey of Cleveland.

Today's women workers begin at all ages. The largest number started at between eighteen and twenty years, the second largest at between sixteen and eighteen years. While the proportion beginning work at other ages decreases as age increases, six in every hundred women working today bagan work at thirty years of age, or older, $\frac{\text { and }}{3}$ almost two in every hundred began at forty years or more.

Lost of these women, however, began to work at sixteen or seventeen years of age.

The amount of responsibility which one would expect to be shered by both parents, is carried by the mother alone. This is indicated by the table below.

Table 1

MARITAL STATUS OF MOTHERS

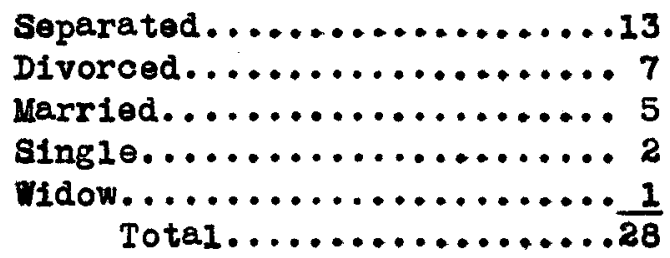

Only five are married and have the help of the father. Are there relatives In the homes to help carry the burden, or do these twenty-three mothers

3U. S. Dep't of Labor, Momen's Bureau Bulletin, No. 183 Vomen Workers in Their Family Rnvironment. (Washing ton: Government Printing Orfice, 1941) p. 3 
carry the responsibility alone? It can be seen from the table below that the age of the mother has some effect on whether relatives or other adulte live with the family. One might think that the ties of the younger woman to ber family would be greater and that more relatives would be living with her. However, the following table indicated that this is not true.

Table 2

NUMBER OF RELATIVES IN HOME ACCORDING TO AGE OF MOTHER

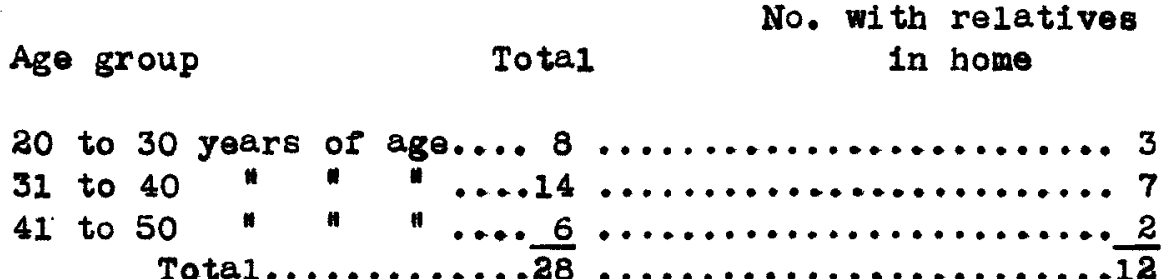

It is the middle group which relies upon the help of relatives. Two of these families have adults other than relatives in the home.

Table 3

REASON FOR MOTHER WORKING ACCORDING TO MARITAL STATUS OF MOTHER

\begin{tabular}{|c|c|c|c|c|c|c|c|c|c|c|c|c|c|c|c|}
\hline \multirow{3}{*}{ Marital Status } & \multirow{2}{*}{\multicolumn{3}{|c|}{ Total }} & \multicolumn{12}{|c|}{ Reason for Working } \\
\hline & & & & \multicolumn{3}{|c|}{$\begin{array}{l}\text { Fallure } \\
\text { to } \\
\text { support }\end{array}$} & \multicolumn{3}{|c|}{$\begin{array}{l}\text { IIlness } \\
\text { of } \\
\text { Eusband }\end{array}$} & \multicolumn{3}{|c|}{$\begin{array}{l}\text { Wanted } \\
\text { to } \\
\text { Separate }\end{array}$} & \multicolumn{3}{|c|}{ Misc.* } \\
\hline & $T$ & $\mathbf{7}$ & $N$ & $\mathbf{T}$ & $w$ & $\mathbf{N}$ & $T$ & 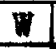 & $N$ & $T$ & $\bar{y}$ & $\mathbf{N}$ & $T$ & $\mathrm{~T}$ & $\mathrm{~N}$ \\
\hline Total & 28 & 18 & 10 & 14 & 11 & 3 & 3 & 2 & 1 & 2 & 1 & 1 & 9 & 4 & 5 \\
\hline Separated & 13 & 7 & 6 & 7 & 5 & 2 & 0 & 0 & 0 & 2 & 1 & 1 & 4 & 1 & 3 \\
\hline Divorced & 7 & 6 & 1 & 5 & 5 & 0 & 1 & 1 & 0 & 0 & 0 & 0 & 1 & 0 & 1 \\
\hline Married & 5 & 3 & 2 & 2 & 1 & 1 & 2 & 1 & 1 & 0 & 0 & 0 & $I$ & 1 & 0 \\
\hline Single & 2 & 1 & 1 & 0 & 0 & 0 & 0 & 0 & 0 & 0 & 0 & 0 & 2 & 1 & 1 \\
\hline Pidowed & 1 & 1 & 0 & 0 & 0 & 0 & 0 & 0 & 0 & 0 & 0 & .0 & 1 & 1 & 0 \\
\hline
\end{tabular}

* This includes the two unmarried mothers, the widow and a grandmother who cares for her grandson. One father was unemployed, one was alcoholic, one's income was insufficient. One mother felt that her husband did not contribute sufficient to meet family needs and one wished to move rrom her mother-in-1ew's home.

Does the marital status of the mother affect the reason for her working? The reasons given in Table 3 are the ones for the mother when 
she began to work rather than at the present time. However, most of the reasons which existed at that time still exist. The two unmarried mothers and the widow have no husband to support them and so must work. of the five women with husbands in the home, two husbands are 111 and unable to work. The significant data are that of the 12 mothers, (seven separated and five divorced) who sought employment because the busband failed to support, six fathers are contributing regularly now, An additional two contribute occasional1y. Perhaps the real reason for the mother seeking employment was not failure of the father to support.

Table 4

MARITAI STATUS OF MOTHER ACCORDING TO LENGTH OF EMPLOYIENT AFTER MARRIAGE

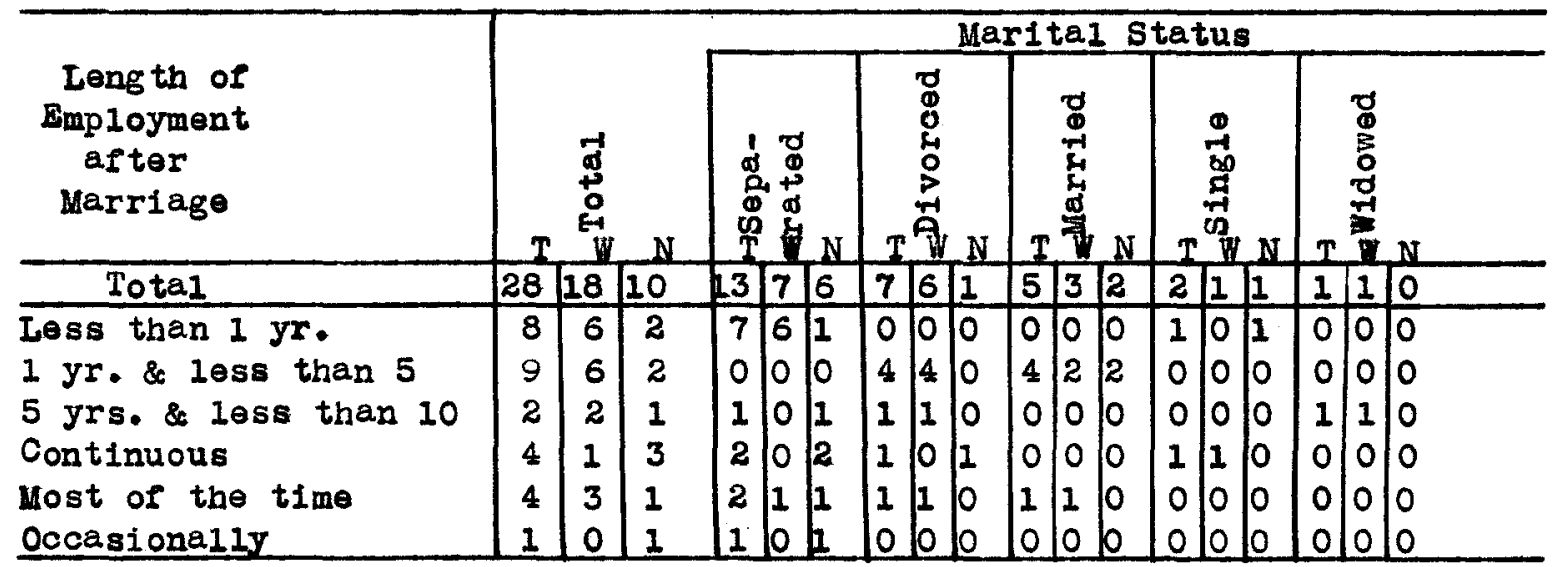

There seems to be some connection in Table 4 between the length of time the mother has worked and her marital status. Seven (four of the separated group, two of the divorced, and one of the married) have worked continuously or most of the time since marriage.

What effect has the mother's employment had upon her marital status? Did the father fall to support because the mother assumed this? 
One can assume that both the length of time the mother has worked and the contribution of her earnings to the family's support had some effect upon her marriage although netther was probably the reason for the marriage being a success or failure. Of those who have been employed five years and less than ten, one is separated, one divoroed, and one widowed. of those working one through four years, four are married and four divorcod. The women working less than one year were separated (seven) and single (one).

\section{Table 5}

MARITAL STATUS OF MOTHER ACCORDING TO EARNINGS OF MOTHER

\begin{tabular}{|c|c|c|c|c|c|c|c|c|c|c|c|c|c|c|c|c|c|c|}
\hline \multirow{3}{*}{ Rarnings } & \multicolumn{18}{|c|}{ Marital Status } \\
\hline & \multicolumn{3}{|c|}{ Total } & \multicolumn{3}{|c|}{ Separated } & \multicolumn{3}{|c|}{ Divorced } & \multicolumn{3}{|c|}{ Married } & \multicolumn{3}{|c|}{ Single } & \multicolumn{3}{|c|}{ Mdowed } \\
\hline & $T$ & 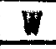 & $\mathrm{N}$ & $T$ & $w$ & $\mathrm{~N}$ & $T$ & Wi & $\mathrm{N}$ & $T$ & W & $\mathrm{N}$ & & W & $\mathrm{N}$ & $\mathbf{T}$ & $\mathbf{D}$ & $\mathrm{N}$ \\
\hline Tota & 28 & 18 & 10 & 23 & 7 & 6 & 7 & 6 & 1 & 5 & 3 & 2 & 2 & 1 & 1 & 1 & 1 & 0 \\
\hline $0-9.99$ & 7 & 1 & 6 & 4 & 1 & 3 & 1 & 0 & 1 & 1 & 0 & 1 & 1 & 0 & 1 & 0 & 0 & 0 \\
\hline $10-1$ & 4 & 2 & 2 & 2 & 1 & 1 & 0 & 0 & 0 & 1 & 0 & 1 & 1 & 1 & 0 & 0 & 0 & 10 \\
\hline $15-19.5$ & 7 & 5 & 2 & 3 & 1 & 2 & 2 & 2 & 0 & 1 & 1 & 0 & 0 & 0 & 0 & 1 & 1 & 0 \\
\hline $20-24.99$ & 7 & 7 & 0 & 3 & 3 & 0 & 2 & 2 & 0 & 2 & 2 & 0 & 0 & 0 & 0 & 0 & 0 & 0 \\
\hline 25 \& over & 3 & 3 & 0 & 1 & 1 & 0 & 2 & 2 & 0 & 0 & 0 & 10 & 0 & 0 & 0 & 0 & 0 & 10 \\
\hline
\end{tabular}

The marltal status of the mother according to her earnings is shown in Table 5. The husbands of two of the married women are unable to work. The three where the husband and wife are living together and are working have weokly incomes as follows:

Table 6

WEBKLY EARNINGS OF MARRIED COUPLIS

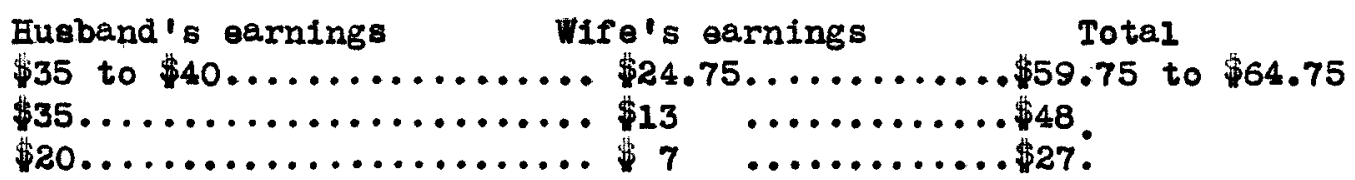

The single mother works because there is no other Income and the widow because she feels it is an Imposition on the two boys to be forced to care 
for her and the four younger children.

The information about the contributions of the father and the earnings of the separated mother are as follows:

Table 7

\section{WREKLY RARNINGS OF SEPARATED COUPLES}

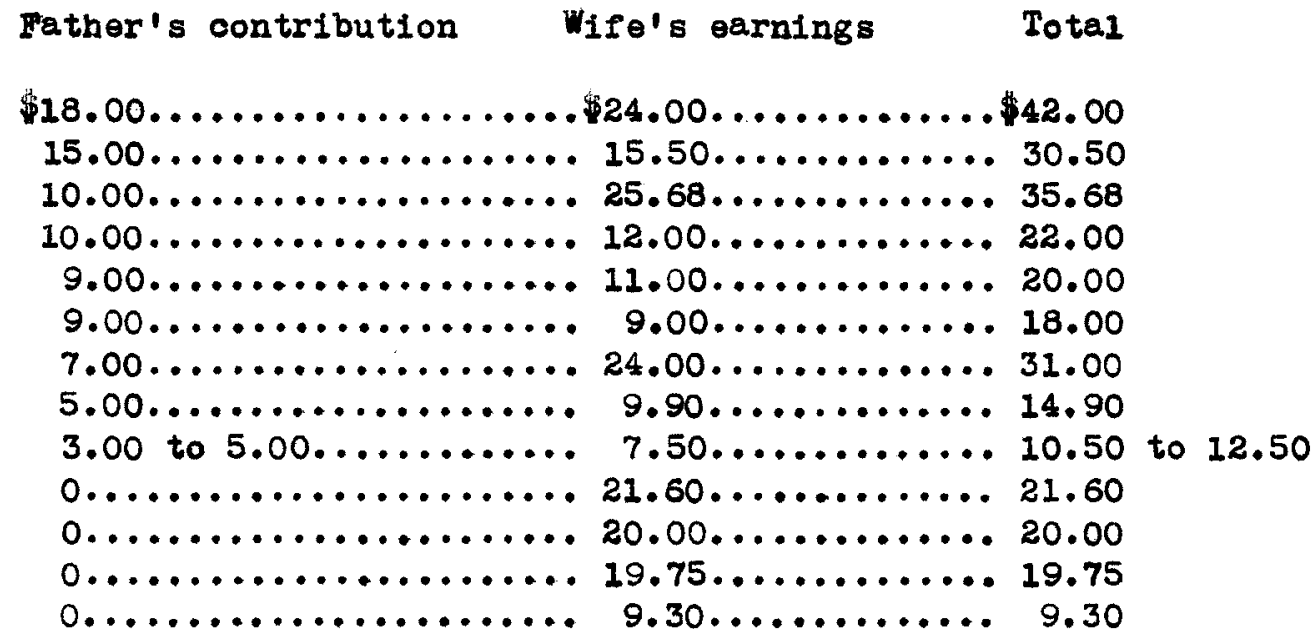

In trying to determine whether or not 1t is necessary for the mother to work in order to meet necessities for the family, there seems to be only one of this group that there might be question about. This, however, is not because the father contributes sufficient to support the famliy but because a boy is working and his board plus the father's contribution would be sufficient to meet expenses. Again referring to material compiled by the Women's Bureau we find that:

The employment of married women is occasioned both by the low annual earning power of the husband, because of irregularity or uncertalnty of employment, and by the demands of relatives for financial assistance. The majority of married women seek employment after experience has demonstrated the family need of their earnings....... Regardiess of marttal status, the wages of the working women are not casual nor supplemental sources of family support.

${ }^{4}$ IbId p. $13-14$ 
In the divorced group, the women seem to have no choice as the two fathers who contribute give such a small amount that it would not be sufficient.

Table 8

WEREIY EARNINGS OF DIVORCED COUPLES

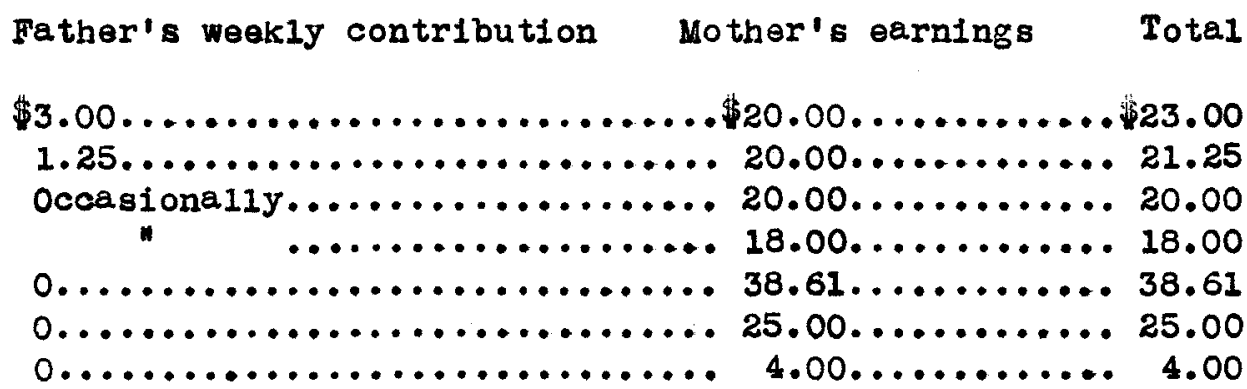

One would think that the more education one had the better opportunity he would have to earn a better salary. The average wage, however, for those with less than an eighth grade education wes $\$ 17.75$ and for the group having an eighth and less than twelfth grade education, it was 16.21. As there was only one who had had more than twelfth grade education, we cannot compute the average. See Table 9.

Tab1e 9

WEEKLY EARNINGS OF MOTHER ACCORDING TO GRADE COMPLETED

\begin{tabular}{|c|c|c|c|c|c|c|c|c|c|c|c|c|}
\hline \multirow{3}{*}{$\begin{array}{l}\text { Weokiy } \\
\text { Earnings }\end{array}$} & \multirow{2}{*}{\multicolumn{3}{|c|}{ Total }} & \multicolumn{9}{|c|}{ Grade completed } \\
\hline & & & & & $\begin{array}{l}8 t \\
8 t h\end{array}$ & & \multicolumn{4}{|c|}{$\begin{array}{ll}\text { 8th \& 1ess } & \\
\end{array}$} & \multicolumn{2}{|c|}{ 12th \& over } \\
\hline & $T$ & 7 & $\mathbf{N}$ & $T$ & 7 & $\mathrm{~N}$ & $T$ & T & $\mathrm{N}$ & $T$ & 7 & $\sqrt{N}$ \\
\hline Total & 28 & 18 & 10 & 8 & 5 & 3 & 19 & 13 & 6 & 1 & 0 & 1 \\
\hline$\$ 0-9.99$ & 7 & 1 & 6 & 3 & 0 & 3 & 4 & 1 & 3 & 0 & 0 & 0 \\
\hline $10-14.99$ & 4 & 2 & 2 & 1 & 1 & 0 & 3 & 1 & 2 & 0 & 0 & 0 \\
\hline $15-19.99$ & 7 & 5 & 2 & 1 & 1 & 0 & 5 & 4 & 1 & 1 & 0 & 1 \\
\hline $20-24.99$ & 7 & 7 & 0 & 1 & 1 & 0 & 6 & 6 & 0 & 0 & 0 & 0 \\
\hline 25 \& over & 3 & 3 & 0 & 2 & 2 & 0 & 1 & 1 & 0 & 0 & 0 & 0 \\
\hline
\end{tabular}

Those women, engaged in manufacturing, earn more as an average (\$20.96) than elther of the other groups except the semi-professional 
group according to Table 10. The semi-professional group has only two in it and is too small to be considered. The clerical group averages $\$ 15.50$ a week and the domestic and personal service $\$ 10.05$. There are two white women included in the domestic and personal service group.

There is only one Negro employed in industry. This speofic information about Negro women who are performing other than domestic work is mentioned because there are so few opportunities for Negro women in this community in other types of work. The one Negro clerk was Iormerly employed in the factory. The Negro in the semi-professional group is employed by the Works Progress Administration. The highest Negro wage is $\$ 18.00$ a week, less than half that of the highest white wage, \$38.61.

Table 10

WERKLY RARNINGS OF MOTHER ACCORDING TO OCCUPATIONAL STATUS

\begin{tabular}{|c|c|c|c|c|c|c|c|c|c|c|c|c|c|c|c|}
\hline \multirow{3}{*}{ Barnings } & \multirow{2}{*}{\multicolumn{3}{|c|}{ Total }} & \multicolumn{12}{|c|}{ occupational Status } \\
\hline & & & & \multicolumn{3}{|c|}{$\begin{array}{l}\text { mantu- } \\
\text { facturing }\end{array}$} & \multicolumn{3}{|c|}{ Domestic } & \multicolumn{3}{|c|}{ Cierical } & \multicolumn{3}{|c|}{ Professional } \\
\hline & $\mathrm{T}$ & H & $\mathrm{N}$ & $\mathbf{I}$ & $\mathbf{D}$ & $\mathbf{N}$ & $\mathrm{T}$ & $W$ & $\mathbf{N}$ & $T$ & D & $\bar{N}$ & $T$ & $\bar{T}$ & $\mathrm{~N}$ \\
\hline Tota1 & 28 & 18 & 10 & 13 & 12 & 1 & 9 & 2 & 7 & 4 & 3 & 1 & 2 & 1 & 1 \\
\hline $10-9.99$ & 7 & 1 & 6 & 1 & 0 & 1 & 6 & 1 & 5 & 0 & 0 & 0 & 0 & 0 & 0 \\
\hline $10-14.99$ & 4 & 2 & 2 & 1 & 1 & 0 & 2 & 0 & 2 & 1 & 1 & 0 & 0 & 0 & 0 \\
\hline $15-19.99$ & 7 & 5 & 2 & 3 & 3 & 0 & 0 & 0 & 0 & 3 & 2 & 1 & 1 & 0 & 1 \\
\hline $20-24.99$ & 7 & 7 & 0 & 6 & 6 & 0 & 1 & 1 & 0 & 0 & 0 & 0 & 0 & 0 & 0 \\
\hline 25 \& over & 3 & 3 & 0 & 2 & 2 & 0 & 0 & 0 & 0 & 0 & 0 & $\underline{0}$ & 1 & 1 & $\underline{0}$ \\
\hline
\end{tabular}

The length of time the mother has held her present employment according to occupational status is shown in Table 11. Most of the domestics were employed by the day and this type of employment is usual1y of shorter duration. In the manufacturing group, nine of the thirteen have held their present positions less than a year. General business conditions are such that more jobs are available and better wages are being offered. More of 
the clerical group held their positions for longer periods than any other. The semi-professional group average was short because it included a practical baby nurse, whose jobs usualiy lasted two weeks.

Table 11

OCCUPATIONAL STATUS OF MOTHER ACCORDING

TO LENGTH OF PRESENT BHPLOYMENT

\begin{tabular}{|c|c|c|c|c|c|c|c|c|c|c|c|c|}
\hline \multirow{3}{*}{ Occupational status } & \multirow{2}{*}{\multicolumn{3}{|c|}{ 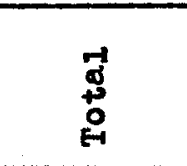 }} & \multicolumn{9}{|c|}{ Length of Present Bmployment } \\
\hline & & & & \multicolumn{3}{|c|}{ 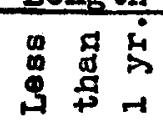 } & \multicolumn{3}{|c|}{ 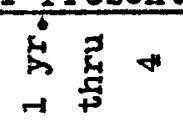 } & \multicolumn{3}{|c|}{$\begin{array}{ll}\text { \& } \\
\text { n }\end{array}$} \\
\hline & $T$ & 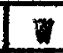 & $\mathrm{N}$ & $T$ & w & $\mathrm{N}$ & $\mathrm{T}$ & $\pi$ & $\mathbf{N}$ & $T$ & 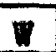 & $\mathrm{N}$ \\
\hline Total & 28 & 18 & 10 & 20 & 18 & 8 & 6 & 5 & 1 & 1 & 0 & 1 \\
\hline Manuracturing & 13 & 12 & 1 & 9 & 8 & 1 & 3 & 3 & 0 & 0 & 0 & 0 \\
\hline Domestic \& Personal Service & 9 & 2 & 7 & 9 & 2 & 7 & 0 & 0 & 0 & 0 & 0 & 0 \\
\hline Clerical & 4 & 3 & 1 & 1 & & 0 & 2 & 2 & 0 & 1 & 0 & 1 \\
\hline Semi-Professional & 2 & 1 & 1 & 1 & 1 & 10 & 1 & 0 & 1 & 0 & 0 & 0 \\
\hline
\end{tabular}

The small amount of time lost from work during the month of october by these mothers was surprising according to Table 12.

Table 12

OCCUPATIONAL STATUS OF MOTHER ACCORDING

TO TIME LOST DURING OCTOBER, 1942

\begin{tabular}{|c|c|c|c|c|c|c|c|c|c|c|c|c|c|c|c|}
\hline \multirow{3}{*}{$\begin{array}{l}\text { Time Lost During } \\
\text { October, } 1942\end{array}$} & \multirow{2}{*}{\multicolumn{3}{|c|}{$\begin{array}{l}\text { 尔 } \\
+3 \\
0 \\
0\end{array}$}} & \multicolumn{12}{|c|}{ Ocoupational Status } \\
\hline & & & & & \begin{tabular}{l}
1 \\
$\dot{4}$ \\
\multirow{3}{3}{} \\
0 \\
0 \\
0 \\
4
\end{tabular} & $\stackrel{\dot{q}}{\dot{\phi}}$ & \multicolumn{3}{|c|}{ 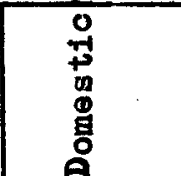 } & \multicolumn{3}{|c|}{ 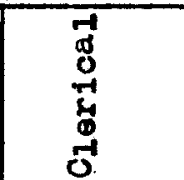 } & \multicolumn{3}{|c|}{ 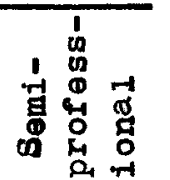 } \\
\hline & $T$ & $\bar{F}$ & $N$ & $T$ & In & $\mathrm{N}$ & $T$ & & $\pi$ & $T$ & & $\pi$ & $T$ & 17 & 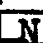 \\
\hline Total & 28 & 18 & 10 & 13 & 12 & 1 & 9 & 2 & 7 & 4 & 3 & 1 & 2 & 1 & 1 \\
\hline None & 13 & 7 & 6 & 5 & 5 & 0 & 4 & $\overline{0}$ & 4 & 2 & 1 & 1 & 2 & 1 & 1 \\
\hline 1 day & 4 & 3 & 1 & 3 & 2 & 1 & $i$ & 1 & 0 & 0 & 0 & 0 & 0 & $\overline{0}$ & 0 \\
\hline 2 days & 3 & 2 & 1 & 2 & 2 & 0 & 1 & 0 & 1 & 0 & 0 & 0 & 0 & 0 & 0 \\
\hline 3 days \& less than I weok & 2 & 2 & 0 & 1 & 1 & 0 & 0 & 0 & $\overline{0}$ & 1 & 1 & 0 & 0 & 0 & 0 \\
\hline 1 week and 10 sa than 2 & 1 & 1 & 0 & 0 & 0 & 0 & 0 & 0 & 0 & 1 & 1 & 0 & 0 & 0 & 0 \\
\hline 2 weeks \& over & 5 & 3 & 2 & 2 & 2 & 0 & 3 & 1 & 2 & 0 & 0 & 0 & 0 & & 0 \\
\hline
\end{tabular}

The semt-professionel group and one-half of the clerical group lost no time.

Four out of nine in domestic service and five out of thirteon in manufecturing lost no time. Thirteen of the twenty-eight, then, lost no time during this 
month. This seems to be an unusually good reoord when one considers the numerous responsibilities which these mothers have. The average amount of time lost was 3.27 day during the month. Iliness of the mother was the most prevalent cause; forty days being lost for this reason. Iliness of child, attendance at children's clinic, or worry over child caused the loss of eight and one-half days. Insufficlent work accounted for thirty days. The average number of days lost by the various groups was:

Table 13

NUMBER OF DAYS MMPLOYHENT LOST BY MOTHER ACCORDING TO OCCUPATIONAL STATUS

Group Average number of days lost

Semi-professional..............00

Clerical....................25

Manufacturing ..................... 81

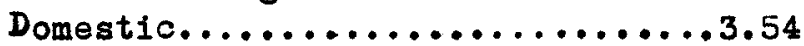

As most of the 1liness was in the domestic group, thirty-two of thirty-nine days, and as domestios earn the smaller wage, there seems to be some connection between inadequate wages and health. Thirty days were lost by lack of work. Th1s might seem peculiar considering all of the publicity about the labor shortage in Louisville, However, few of the women (four) are employed in defense work and as production in many other industries is being slowed or halted entirely, this amount does not seem out of proportion.

Do these women lose money when not working? This information was not requested but from our general knowledge of the type of work and the employment policies, it is very doubtful if they are pald for any time lost.

In the discussion, the twenty-eight families with which this study is concerned. we have analyzed carefully the role played by the mother; but Inevitably in any study involving the ramily unit many other phases of family 
life must be included. It is with this in mind that the following miscellaneous data is included.

There were eighteen relatives living in the homes with ten of the families. There were also three other adults living with two of our families. Some of these relatives contributed to the support of the family. Some shared in the housework and care of the children and some were an additional responsibility. Only four made any monetary contribution:

Tab1e 14

WERKLY CONTRIBUTIONS OF OTHER ADULTS LIVING

VITH FAMIIY

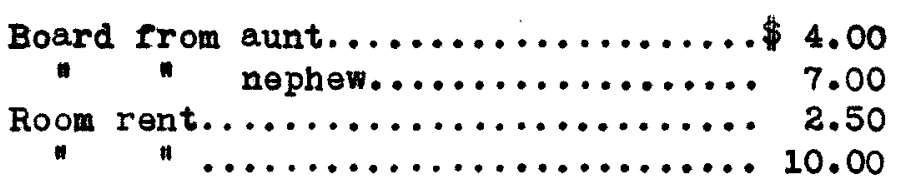

Further light on this question as to who has the financial responsibility is brought out in Table 15. It indicated the number of wage earners according to the size of the family. The mother was the only earner in half of the families (fourteen); in twelve cases there was one additional wage earner and in two families there were two to help. The size of the family influenced the number of wage earners slightly.

Table 15

WAGE EARNERS INCLUDING MOTHER ACCORDING TO NUMBER IN HOUSEHOLD

\begin{tabular}{l|c|c|c|c|c|c|c|c|c}
\hline & & \multicolumn{10}{|c}{ Bize of Family } \\
\cline { 3 - 10 } \multicolumn{1}{c|}{ Wage Earners } & Total & 1 & 2 & 3 & 4 & 5 & 6 & 7 & 8 \& over \\
\hline One & 14 & 1 & 3 & 4 & 4 & 0 & 1 & 1 & 0 \\
Two & 12 & 0 & 1 & 2 & 4 & 1 & 1 & 1 & 2 \\
Three & 2 & 0 & 0 & 1 & 0 & 0 & 0 & 0 & 1 \\
\hline
\end{tabular}

In this chapter, we have attempted to give an overall plcture of 
twenty-eight working mothers in the city of Louisvil1e. We have tried to show the environment under which they work and 11ve; the problems which they meet with success or failure. If one were to consider only one phese of the mother's problem - - time - - that, above al1, shows clearly how great the sacrifice, which the mother makes and how ineffective her efforts must be because she must cover so many phases of existence. 
CEAPTER II

HOUSEHOLD PLANNING 


\section{Chapter II}

\section{Household Planning}

In trying to define the working mother's responsibilities aside from that of earning the living for the family, inquiry was made as to who performs the various household tasks. This information regarding the mothers' labor and contribution to the family aside from her earnings is particularly signiflcant when compared with material secured by the U. S. Bureau or Home Economics, Department of Agriculture, in 1936 regarding the amount of time necessary to perform household tasks.

The Bureau analyzed the schedules of more than 2,000 homemakers after the homemakers had kept daily records of how they spent their time for several days of a typical week. The homemakers came from farms and villages, and in smaller numbers from towns and cities. Only one-sixth spent as little as fortytwo hours a week in homemaking; five-sixths of them spent over forty-two hours a week, more than half over forty-eight hours and one-third spent over fifty-six hours. The average for all was slightly over fifty-one hours a week.

In larger cities of 50,000 and over the average was a little above forty-eight hours a week and only ten percent of the women spent less than thirty-five hours a week in their homemaking. 1

Wen we compare this with the mothers in our cases, it certeiniy makes us wonder when they find time to sleep. The mother In twenty-five of our twenty-eight cases has the responsibility for household planning and supervision. In another study of rural homemakers $^{2}$ (New York $S_{\text {tate) }}$ it was indicated that 51.88 hours a week

$1_{U}$. S. Department of Labor, Women's Bureau Bulletin, No. 155 Women in the Economy of the United States of Amerioa, (Washington: Government Printing office, 1937) P. 30

$$
\text { 2Ibid, p. } 31
$$


was spent in housework. This study from New York State was selected because it had more urban population included and because the breakdown of housework was similar to that used in our schedule. Further mention of this study is made in the final conclusions of this chapter. Management took 1.57 hours per week. It seems logical to consider a similar amount of time for these mothers.

The washing which is probably the heaviest task in most homes was done by the mother either after getting home from work, before going to work, or on Sundays. In thirteen of the twenty-eight families, the mother had entire responsibility for this, as noted in Table 16. Where there were other women living with the family, the mother was not responsible for washing as in only one of the eight families in this category did the mother do the washing. In four of the twenty-eight, she shared this with another member of the family or with the maid. Six sent part of the wash to the 1aundry. Three of the four who shared responsibility were familfes with other adults; two of the four had daughters over fifteen who helped. In only five was the mother relieved of all responsibility for this. In the smaller ramilies, having one to three members (ten), the mother had all responsibility in five and had to help in one more.

Other factors usually make the washing heavier in families with small Incomes. Fewer clothes requires washing more often. Several of the mothers indicated that they wash more than once a week. Small children, particularly those under one year, require more washing. In the three families with children under one year, the mother had sole responsibility in one, and shared it in one. Eleven families had 
children in the age group of one year and less than six years. Three of these had two or more children. The mother did the washing in seven and shared it in two more.

The contrast between arrangements made in white famliies and those made in Negro families is interesting. None of the Negro families had any hired help in the home. The fact that four of the ten families had seven or more individuals may influence this but there is also the fact that the Negro wage is small and that he is more willing to share what he has. Four of ten Negro families had relatives living with them in contrast to four of eighteen of the white. Negro mothers seemed to assume more respnnsibility for the washing. In contrast to this, the white mother did the wash in only seven of eighteen.

The total, then, for both white and Negro mothers assuming entire responsibility is thirteen. Negro mothers assuming all responsibility and those assuming part for the weshing were seven of the ten whereas the number for the same group in the white families was only ten of eighteen. None of the Negroes sent all of the wesh to the laundry. Two of the Negroes and four of the white, sent part to the laundry.

Responsibility for the ironing is divided very similarly to that for the washing, the mother having sole responsibility in fourteen cases and belping in six others as shown in Table 16. The children took over this task in two, other nembers in two and the maid in three. Again we notice a similarity in that in the larger families, six members and over, the mother was relieved of this. The smaller family again shifted this responsibility to her shoulders as in those with one to five members (ten) the mother had responsibility in seven and helped in two others. The same 
Table 16

PERFORMANCE OF HOUSHOLD TASKS ACCORDING TO MEMBER OF HOUSEHOLD \& RACE

\begin{tabular}{|c|c|c|c|c|c|c|c|c|c|c|c|c|c|c|c|}
\hline \multirow[b]{2}{*}{$\begin{array}{c}\text { Eousehold } \\
\text { Task }\end{array}$} & \multicolumn{15}{|c|}{ Task Performed by } \\
\hline & \multicolumn{3}{|c|}{$\begin{array}{r}\text { Mother } \\
\text { Alone } \\
\end{array}$} & \multicolumn{3}{|c|}{$\begin{array}{c}\text { Mother } \\
\text { with Help }\end{array}$} & \multicolumn{3}{|c|}{$\begin{array}{l}\text { Other Member } \\
\text { of Household }\end{array}$} & \multicolumn{3}{|c|}{ Onildren } & \multicolumn{3}{|c|}{$\begin{array}{c}\text { Other } \\
\text { Sources * }\end{array}$} \\
\hline & $T$ & 需 & $\mathrm{N}$ & $T$ & W & $\mathrm{N}$ & $\mathrm{T}$ & $W$ & $\mathbf{N}$ & $T$ & $\bar{W}$ & $\mathrm{~N}$ & $\mathrm{~T}$ & $W$ & $\mathbf{N}$ \\
\hline Household planning & 25 & 16 & 9 & 1 & 1 & 0 & 2 & 1 & 1 & 0 & 0 & 0 & 0 & 0 & 0 \\
\hline Washing & 13 & 7 & 6 & 4 & 3 & 1 & 4 & 3 & 1 & 0 & 0 & 0 & 7 & 5 & 2 \\
\hline Ironing & 14 & 8 & 6 & 6 & 4 & 2 & 2 & 1 & 1 & 2 & 1 & 1 & 4 & 4 & 0 \\
\hline Cooking & 14 & 10 & 4 & 3 & 2 & 1 & 5 & 2 & 3 & 5 & 3 & 2 & 1 & 1 & 0 \\
\hline Marketing & 16 & 9 & 7 & 4 & 4 & 0 & 3 & 1 & 2 & 5 & 4 & 1 & 0 & 0 & 0 \\
\hline Clearing Away & 5 & 2 & 3 & 7 & 6 & 1 & 1 & 1 & 0 & 13 & 7 & 6 & 2 & 2 & 0 \\
\hline Cleaning & 11 & 6 & 5 & 7 & 5 & 2 & 3 & 2 & 1 & 5 & 3 & 2 & 2 & 2 & 0 \\
\hline Care of Fire & 2 & 0 & 2 & 5 & 4 & 1 & 3 & 0 & 3 & 3 & 2 & 1 & 2 & 2 & 0 \\
\hline Yard Work & 6 & 3 & 3 & 0 & 0 & 0 & 3 & 0 & 3 & 3 & 2 & 1 & 16 & 13 & 3 \\
\hline Mending & 22 & 14 & 8 & 4 & 3 & 1 & 2 & 1 & 1 & 0 & 0 & 0 & 0 & 0 & 0 \\
\hline
\end{tabular}

* Tasks performed by maid, landlord, or sent to laundry. 
contrast which was noted earlier between Negro and white families is again seen in planning for the ironing. Six of the ten Negro mothers had sole responstbility in comparison with eight of eighteen of the white mothers. The combination of mothers assuming all responsibility and those assuming part was eight of ten for the Negro mothers and eleven of eighteen for the white.

The same studies mentioned above indicate ${ }^{3}$ that it requires 5.35 hours per week for the washing and ironing. The average number of persons in the household was 4.1 in the city and 4.4 on the farm. In our study the average number is 4.64 . Where there was a small child in the household, the total working time necessary for housework was raised six hours a week and where there was a child under one year, thirteen hours a week. This does not include time spent in walking with them, "airing the baby," or other recreation. Another factor in both these tasks and other house work is the fact that most of our families have limited equipment. Many do not have sufficient bedding, pots and pans, and other necessities. Few have conveniences such as vacuum cleaners, electric refrigerators, et cetera. Those living in the housing projects, of course, have tiled baths, electric refrigerators, new gas stoves, et cetera. Six of this group were living in one of the projects. The rest for the most part were living in substandard housing and had inadequate household equipment. Cooking, too, presents its problems. In addition to the tasks of marketing, preparing the mea1s, and clearing away, there is the necessity frequently of planning for meals while the mother is away from home. Children who are in school can seoure a hot meal there but younger 
children must be considered. Referring back to the Home Economics Survey, we note that about one-third of the homemakers time is taken up in preparation of meals. Taking the lowest estimate of time needed for household duties, thirty-rive hours a week, approximately twelve hours a week would be spent for this task. Fourteen of our mothers did all of the cooking, and three did with some help. In eleven households the cooking was done by either another member of the family or the maid.

Marketing also required the mothers' time and energy. Many remarked that it was difficult to have another person do this as it was more expensive. Children particularly were prone to buy more expensive foods and the mother, therefore, felt it necessary to perform this task herself. In sixteen families she had no help; in four the mother and some other member did the purchasing; the children performed this in five; in three another member assumed this task; and in none was this responsibility given to someone outside the family.

In this phase of housework we see a contrast in planning between the Negro and white families. The mother in the white families assumes this responsibility in ten of eighteen and in the Negro, four of ten. When we add those who assume part responstbility, the total becomes only eleven of eighteen for white and five of ten for Negroes. One cannot help wondering why this division of labor? Ig it because the white mother feels that cooking is more important than the Negro mother does? Is it because of the age groups of the families? Is it because of the hours of employment? Children do the cooking in two of the Negro families and in tbree of the white. Other members cook in three of the Negro and two of the white.

${ }^{4}$ Ibid., p 32 
Half of the white mothers do all of the purchasing and seven of the Negro mothers do it. Another four of the white mothers have some help in doing the marketing whereas the Negro mother either performs this task herself or assigns it to some other member. White children are more frequently entrusted with this responsibility (four of eighteen) than Negro children (one of ten).

Very few of our families do any baking, four regularly and eleven occasionaliy. Most of them considered this too much additional work. The same was true of canning, only four doing any. The canning was affected somewhat by the sugar rationing program as several motbers indicated that they had canned some in the past but felt it was not worth while this year. The children assumed more responsibility for the dish washing and clearing away than for any other household task. Here again this was affected by the age of the children and by the mothers' feeling that it was easier to perform this task herself. In thirteen the children performed this task in contrast to the mothers' doing it in five families and helping in seven others. The maid had this task in two and another member of the ramily in one. This is the only task noted in which any of the mothers stated that the father helped. The boys, too, helped In this task; they were not expected to help in other tasks except the care of the fire.

Negro children (six of ten) assume more responsibility for clearing away than do white children (seven of eighteen). However, Negro mothers again either perform this task by themselves, (three) or with some help, (one). Wite mothers only do this in two families, and belp in six. The maid takes care of this in two white families. 
Cleaning seems to be another burden of the working mother as eleven assume full responsibility and seven others help with this work. The mother is relieved of this in ten families; five by children, three by other members and two by the maid. Again we note that the mother of small families has to assume responsibility for a larger number of tasks and that she is relieved of some in the larger families; she has no responsibility for cleaning in three of the larger families (seven and more members) has help in four and had full responsibility in one. Here again more Negro mothers than white assume this responsibility (one-half of the Negro and one-third of the white). The white mother has some help with this task in five and is relieved of it in seven, three by children, two by other members, and two by maid. The Negro mother has help in two, and is released from this task in three, two by the children and one by other members. This task according to the Home Economics Study adds another 8.25 hours work a week.

Heat is furnished in thirteen (ten of which are white and three are Negro) of the twenty-eight homes. Families Iiving in the municipally owned housing projects have heat furnished as well as gas, electricity, and water. There are four white and two Negro families living in these projects. With the exception of one, the remainder of the white families, where heat is furnished, are living in furnished rooms.

In the homes where the family provide their own heat the mother looks after the fires in only two cases and these are both Negro. She helps with this in five, four of which are white. In three Negro families, another member of the family looks after the fire. In three families this 
is the children's responsibility (two white and one Negro) and in two families (white) the maid cares for the fires.

Fifteen of the families do not have a yard or do not have the task of caring for it. Twelve of these are white and three Negro. The mother has the task of caring for the yard in six, (three white and three Negro). The children cut the grass and do the cleaning up in three (two white and one Negro) the maid in one and another member in three (Negro).

Half of the families purchase ready-made clothing, thirteen do some sewing, but only one makes all clothingat home. Several indicated that a sewing machine was greatly needed and would change the picture from ready made to home made clothing. The mother had all the mending and repairing of clothing in twenty-two families and shared this in four others. In only two instances was this task assumed by another member of the household.

In trying to make an estimate of the average time spent by these mothers in household tasks, it seems logical to select one of the surveys made by the U. S. Bureau of Fome Economics and use it as a guide. We selected the one made by Women's Bureau in New York State ${ }^{6}$ as has been mentioned before. It is indicated in Table 17 that the mother spends an average of thirty-two plus hours per week on household tasks. When this is added to forty-seven hours, the average number of hours per week the mother works and the time spent going to and from her employment, one can see more clearly the real sacrifice the mother is making on the total responsibility of support for the family plus the care of the housework.

$$
{ }^{6} \text { Ibid., p } 32
$$


TIME NEEDED FOR VARIOUS TASKS ACCORDING TO U. S. BURBAU

OF HOME ECONOMICS, NBW YORK SURVEY \& APPROXIMATE

AMOUNT SPENT BY WORKING MOTEHERS

\begin{tabular}{|c|c|c|c|}
\hline Task Performed & 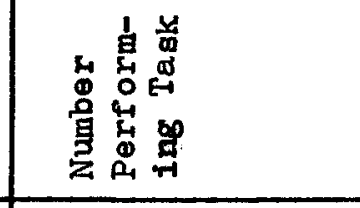 & 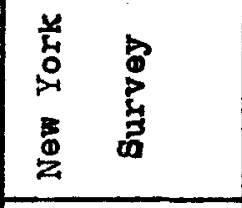 & 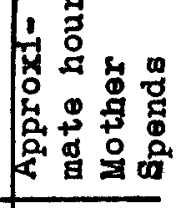 \\
\hline Total & & $\begin{array}{c}\text { No. of Hours } \\
45.73\end{array}$ & 32.16 \\
\hline $\begin{array}{c}\text { Household planning by mother alone } \\
\text { with help }\end{array}$ & $\begin{array}{r}23 \\
1\end{array}$ & 1.57 & $1.57^{\mathrm{b}}$ \\
\hline $\begin{array}{r}\text { Washing by mother alone } \\
\text { with help }\end{array}$ & $\begin{array}{r}13 \\
4\end{array}$ & 3.17 & $1.58^{\circ}$ \\
\hline $\begin{array}{r}\text { Ironing by mother alone } \\
\text { with help }\end{array}$ & $\begin{array}{r}14 \\
6\end{array}$ & 2.18 & $2.18^{\mathrm{b}}$ \\
\hline $\begin{array}{c}\text { Cooking-includes marketing- } \\
\text { by mother alone } \\
\text { with help }\end{array}$ & $\begin{array}{cc}\text { Cooking } & \text { Marketing } \\
14 & 16 \\
3 & 4\end{array}$ & 17.35 & $17.35^{b}$ \\
\hline $\begin{array}{c}\text { Clearing away by mother alone } \\
\text { with help }\end{array}$ & $\begin{array}{l}5 \\
7\end{array}$ & 8.50 & $2.55^{\mathrm{d}}$ \\
\hline $\begin{array}{c}\text { Care of fires by mother alone } \\
\text { with help }\end{array}$ & $\begin{array}{l}2 \\
5\end{array}$ & 2.28 & $.38^{b}$ \\
\hline $\begin{array}{r}\text { Mending by mother alone } \\
\text { with help }\end{array}$ & $\begin{array}{r}22 \\
4\end{array}$ & 2.43 & $2.43^{\mathrm{b}}$ \\
\hline $\begin{array}{r}\text { Cleaning by mother alone } \\
\text { with help }\end{array}$ & $\begin{array}{r}11 \\
7\end{array}$ & 8.25 & $4.12^{c}$ \\
\hline
\end{tabular}

QU.S. Dep't or Labor, Women's Bureau Bulletin No. 155 -Women in the Economy of the United States of America (Washington: Govt. Printing Orfice 1937) p. 32

bren more than half of the mothers performed the task the same Iigure was used.

When the total number of mothers performing the task alone and sharing the work was more than half, half of the time was used.

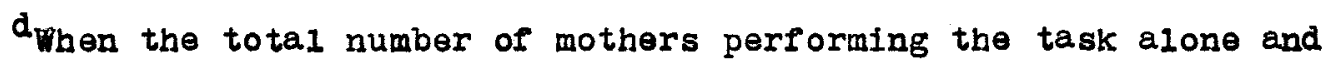
sharing the work was less than half, the percentage of the total families for the number of mothers performing the task was multiplied by the hours of the New York Survey and added to one-half of the percentage of the total for the mothers sharing the work. 
CHAPTER III

CHILDREN AND THEIR CARE 


\section{Chapter III}

\section{Children and Their Care}

In the twenty-elght families studied there were eighty-seven children ranging in age from three months to twenty-one years. ${ }^{1}$ Fifty of these were white and thirty-seven were Negro. This made an average of 2.77 children per white family and 3.70 per Negro family, and an average for the group of 3.10 children per family.

Table 18

NUMBER OF CHILDREN ACCORDING TO AGE GROUPS

\begin{tabular}{|c|c|c|c|c|c|}
\hline 8 & were & Iess & than & one & year \\
\hline 19 & $"$ & 1 year & through & 5 & years \\
\hline 26 & " & 6 years & $n$ & 10 & $H$ \\
\hline 19 & " & 11 & 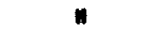 & 15 & $\omega$ \\
\hline 16 & $n$ & 16 & $\omega$ & 20 & $\|$ \\
\hline 2 & $\omega$ & 21 & & & \\
\hline
\end{tabular}

$$
\text { Total - } 87
$$

Seventeen of these were pre-school children, fifty were in school (three of whom were working), six were working, four were unemployed, three were housekeepers, and seven were out of the home. Further information regarding school placement is included in the later part of this Chapter. ${ }^{2}$ only five children of sixteen years and over have continued in school.

This is in contrast to thirteen others who have dropped out of school. Nineteen of the school children are retarded in their studies,

${ }^{1}$ These mothers have ten other children who are not included in this study because they are not part of the family and have not been for some months. One is living with grandparents, three are with their father, one is at the signal corps school, one is in the Navy, one is in a Tuberculosis sanitarlum, one is in a monastery and two are working away from home.

$2_{\text {See }}$ pages $44-45$ 
if one considers that a child should be in the first grade when six, second grade when seven and so on. Four were more than one grade behind. One can not help 'wondering how much the strain of the mother's working has influenced th1s. Of course, there probably are other causes such as additional strain due to marital difficulties of parents, low mentality, and illness of the child. The child may not be regular in attendance because his mother is not at home to see that he gets to school. Any way one looks at it, it seems to indicate that the work of the mother has a direct bearing on the child's ability to keep up with his school work. One must also take into consideration that we are dealing with a very small group of families and that this picture may not be true of a larger group. On the other hand one sees that one child is making better progress in school than the average, being fifteen years old and in the eleventh grade.

The children, of sixteen years and over, who have gone to work have probably done so at an early age because of the financial strain within the home. Of the thirteen in this group, six are employed and three are the homemakers. Only four are not making some contribution to the home---those who are unemployed.

Table 19

\section{RARNINGS OF CHILDREN}

Contributions Number of persons

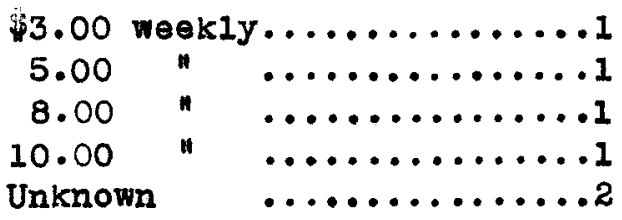

3 or these four who are unemployed one is 111 (rheumatic heart disease), one had joined the army and was expecting to leave in a few days, one had recently lost his job (cause unknown), and one had been in constant trouble of some sort or another. 
The care of these eighty-seven children was one of the primary concerns of this study. Most of them were cared for in their own homes by relatives living with them; a few were lert without supervision. Some were cared for by neighbors, landlorda, and so forth, as indicated in Table 20. Or the eighty-seven children, sixty-nine were cared for at home, forty-five by relatives, twelve by non-relatives, the maid or landlord, and twelve were left alone. An additional six were cared for by relatives outside the home. Neighbors looked after three, and nine of the children were under the care of social agencies; five being placed in institutions or in foster homes; and four in the day nursery.

Most Negro familiea make arrangements to look after the children at home, thirty-one of thirty-seven, Twenty-eight of them were under the care of relatives. The other three were supervised by the landlord. Four children were placed in Dast Fnd Day Nursery.

The white children were not so well looked after; thirty-elght of the fifty were at home, seventeen were under the supervision of relatives, nine under the supervision of the maid, and twelve were left without supervision. An additional five were cared for by relatives outside the home and two were left with a neighbor. Five children were placed; three were in a foster home under the supervision of ormsby Village, one was in a Catholic orphanage, and one was in Home of the Innocents. With the exception of one, these children who were placed were under rive years or age.

Plans for the care of differing age group of children varied considerab1y. Four of the five babies, less than one year, were cared for in their own homes. The children between one and five (twenty) were 
Tab1e 20

TYPE OF CARE OF CHILDRIN ACCORDING TO AGES OF CHIIDRBN

\begin{tabular}{|c|c|c|c|c|c|c|c|c|c|c|c|c|c|c|c|c|c|c|c|c|c|}
\hline \multirow{3}{*}{ Type of care } & \multicolumn{21}{|c|}{ Ages of Children } \\
\hline & \multicolumn{3}{|c|}{ 樟 } & \multicolumn{3}{|c|}{ 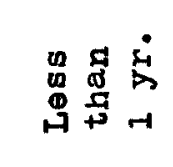 } & \multicolumn{3}{|c|}{ 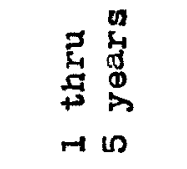 } & \multicolumn{3}{|c|}{ 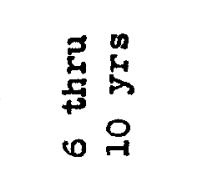 } & \multicolumn{3}{|c|}{ 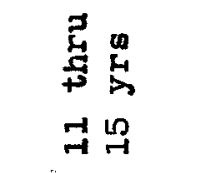 } & \multicolumn{3}{|c|}{ 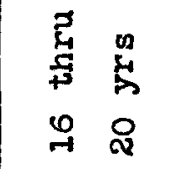 } & \multicolumn{3}{|c|}{\begin{tabular}{l}
$\infty$ \\
\multirow{2}{\alpha}{} \\
$\vec{v}$
\end{tabular}} \\
\hline & $T$ & $\mathrm{PI}$ & $\mathbf{N}$ & $T$ & $\bar{N}$ & $\mathrm{~N}$ & $\mathrm{~T}$ & 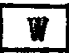 & $\mathbf{N}$ & $T$ & W & $\mathbf{N}$ & $T$ & D & $\mathrm{N}$ & $T$ & $W$ & $\mathbf{N}$ & $T$ & W & $\bar{N}$ \\
\hline Total & 37 & 50 & 37 & 5 & 2 & 3 & 19 & 11 & 8 & 26 & 14 & 12 & 19 & 14 & 5 & 16 & 9 & 7 & 2 & 0 & 2 \\
\hline In home & 69 & 38 & 31 & 4 & 1 & 3 & 10 & 5 & 5 & 19 & 10 & 9 & 19 & 14 & 5 & 15 & 8 & 7 & 2 & 0 & 2 \\
\hline Relatives & 45 & 17 & 28 & 4 & 1 & 3 & 7 & 2 & 5 & 9 & 3 & 6 & 11 & 6 & 5 & 12 & 5 & 7 & 2 & 0 & 2 \\
\hline Non-relatives & 12 & 9 & 3 & 0 & 0 & 0 & 2 & 2 & 0 & 7 & 4 & 3 & 2 & 2 & 0 & 1 & 1 & 0 & 0 & 0 & 0 \\
\hline Left alone & 12 & 12 & 0 & 0 & 0 & 0 & 1 & 1 & 0 & 3 & 3 & 0 & 6 & 6 & 0 & 2 & 2 & 0 & 0 & 0 & 0 \\
\hline Outside home & 18 & 12 & 6 & 1 & 1 & 0 & 9 & 6 & 3 & 7 & 4 & 3 & 0 & 0 & 0 & 1 & 1 & 0 & 0 & 0 & 0 \\
\hline Organized social work & 9 & 5 & 4 & 1 & 1 & 0 & 5 & 3 & 2 & 3 & 1 & 2 & 0 & 0 & 0 & 0 & 0 & 0 & 0 & 0 & 0 \\
\hline P1acement & 5 & 5 & 0 & 1 & 1 & 0 & 3 & 3 & 0 & 1 & 1 & 0 & 0 & 0 & 0 & 0 & 0 & 0 & 0 & 0 & 0 \\
\hline Day nursery & 4 & 0 & 4 & 0 & 0 & 0 & 2 & 0 & 2 & 2 & 0 & 2 & 0 & 0 & 0 & 0 & 0 & 0 & 0 & 0 & 0 \\
\hline Relatives & 6 & 5 & 1 & 0 & 0 & 0 & 1 & 1 & 0 & 4 & 3 & 1 & 0 & 0 & 0 & 1 & 1 & 0 & 0 & 0 & 0 \\
\hline Non-relatives & 3 & 2 & 1 & 0 & 0 & 0 & 3 & 2 & 1 & 0 & 0 & 0 & 0 & 0 & 0 & 0 & 0 & 0 & 0 & 0 & 0 \\
\hline
\end{tabular}


also cared for mostly in their own homes. Negro children again seemed to be more adequately cared for than the white, by relatives (five) at home, one by a neighbor, and two at the day nursery. The white children were not so fortunate. Three were cared for by relatives, two in their own home and one outside, two by maid, one by sixteen year old who was left In charge of three children, and two by neighbors. Three of this group were in a foster home and one with grandparents in the country. The group consisting of six to ten year old (twenty-six) did not fare any better. Nine were with relatives at home (six Negro and three white). Another four were cared for by relatives outside the home (three white and one Negro). Four white children were cared for by the maid and three Negro children were cared for by the landlord. Two were sent to the day nursery and one was in the orphanage. The other three were left at home alone.

The care for the eleven to fifteen year olds (nineteen) seemed more adequate. Eleven of nineteen (six white and five Negro) are cared for by relatives and ten are supervised by maids. Two are considered old enough to look arter themselves.

The next group (sixteen through twenty years old) are sixteen in number. Twelve (five white and seven negro) are looked after by relatives in the home and one (white) is taken care of by relatives outside the home. One is cared for by the maid, one is considered old enough to look after himself, and one is left alone.

The children of the single mother are young children, while those of the widow are older as indicated in Table 21. The average number of 
Table 21

MARITAL STATUS OF MOTHER ACCORDING TO AGES OF CHILDREN

\begin{tabular}{|c|c|c|c|c|c|c|c|c|c|c|c|c|c|c|c|c|c|c|}
\hline \multirow{3}{*}{$\begin{array}{c}\text { Ages } \\
\text { of } \\
\text { Children }\end{array}$} & \multirow{2}{*}{\multicolumn{3}{|c|}{$\begin{array}{l}\text { d] } \\
\stackrel{1}{+} \\
0 \\
0\end{array}$}} & \multicolumn{15}{|c|}{ Marital Status } \\
\hline & & & & \multicolumn{3}{|c|}{ 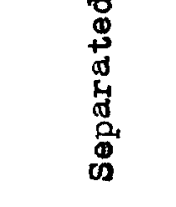 } & \multicolumn{3}{|c|}{$\begin{array}{l}0 \\
0 \\
0 \\
0 \\
0 \\
0 \\
0 \\
\vec{A}\end{array}$} & \multicolumn{3}{|c|}{ 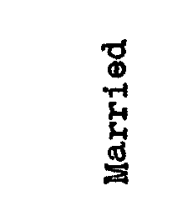 } & \multicolumn{3}{|c|}{\begin{tabular}{l}
$\bar{z}$ \\
0 \\
0 \\
\hdashline \\
\hdashline
\end{tabular}} & \multicolumn{3}{|c|}{$\begin{array}{l}\stackrel{0}{0} \\
\underset{60}{8} \\
-7 \\
010\end{array}$} \\
\hline & $\mathrm{T}$ & $W$ & $\mathrm{~N}$ & $T$ & VI & $\underline{N}$ & $\mathrm{~T}$ & $\mathbf{D}$ & $\mathbf{N}$ & $\mathrm{T}$ & i & $\mathrm{N}$ & $\mathbf{T}$ & 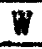 & $\mathrm{N}$ & $T$ & 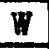 & $\mathrm{N}$ \\
\hline Total & 87 & 50 & 37 & 42 & 17 & 25 & 19 & 18 & 1 & 18 & 8 & 10 & 5 & 5 & 0 & 3 & 2 & 1 \\
\hline Less than $1 \mathrm{yr}$. & 5 & 2 & 3 & 3 & 1 & 2 & 1 & 1 & 0 & 1 & 0 & I & 0 & 0 & 0 & 0 & 0 & 0 \\
\hline 1 yr. \& thru 5 & 19 & 11 & 8 & 11 & 5 & 6 & 3 & 3 & 0 & 3 & 2 & 1 & 0 & 0 & 0 & 2 & 1 & 1 \\
\hline 6 yrs. \& " 10 & 26 & 14 & 12 & 13 & 5 & 8 & 7 & 6 & 1 & 4 & 1 & 3 & 1 & 1 & 0 & 1 & 1 & 0 \\
\hline 11 " \& $" 15$ & 19 & 14 & 5 & 7 & 3 & 4 & 6 & 6 & 0 & 4 & 3 & 1 & 2 & 2 & 0 & 0 & 0 & 0 \\
\hline $16 " \& " 20$ & 16 & 9 & 7 & 7 & 3 & 4 & 2 & 2 & 0 & 5 & 2 & 3 & 2 & 2 & 0 & 0 & 0 & 0 \\
\hline $21 \mathrm{yrs}$ & 2 & 0 & 2 & 1 & 0 & 1 & 0 & 0 & 0 & 1 & 0 & 1 & 0 & 0 & 0 & 0 & 0 & 0 \\
\hline
\end{tabular}


children for the group according to martial status of the mother is quite interesting.

Tab1e 22

TOTAI \& AVERAGE NUWEER OF CHILDREN ACCORDING TO MARITAI STATUS OF MOTHER.

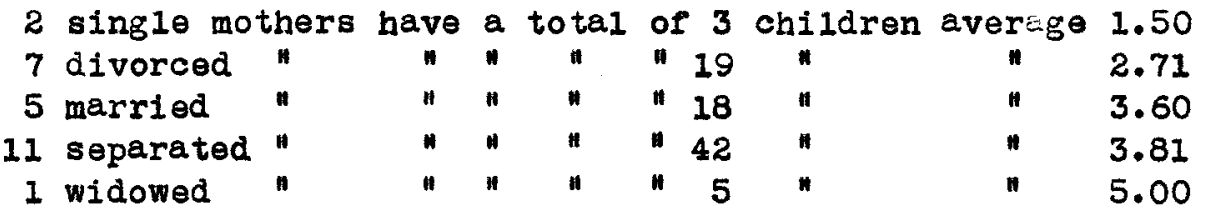

The average for the entire group is $3.10---$ for the white 2.77 and for the Negroes 3.70 .

Table 23, which shows the type of care given the children accordIng to the number of chilaren, confirms the impression that large families have members who may care for the children. There are four families with five or more children all of whom are cared for by relatives. In the smaller families with one to four members, nine were cared for by relatives, four by the maid or landlord, two by neighbors, four by organized social work, and five were left alone.

In thinking about the care of the children, one of the questions which has come up was in connection with the age of the mother. Does the young wother lack judgment in making plans for her children? Is she shlelded and protected by relatives? We had thought that the young mothers might depend more upon relatives and that there would be closer ties especially to the maternal grandmother. However, this is not true; instead it is the older mothers who look to relatives for help as is noted in Table 24. Only one mother under thirty left her chlidren with relatives; whereas four between thirty-one and thirty-five did; four between thirty-six and 
Table 23

TYPL OF CARE OF CHIIDREN ACCORDING TO NUIBBER OF CHIIDREAN

\begin{tabular}{|c|c|c|c|c|c|c|c|c|c|c|c|c|c|c|c|c|c|c|}
\hline \multirow{3}{*}{$\begin{array}{l}\text { Type } \\
\text { of } \\
\text { Care }\end{array}$} & \multirow{2}{*}{\multicolumn{3}{|c|}{ Total }} & \multicolumn{15}{|c|}{ Number of Children } \\
\hline & & & & \multicolumn{3}{|c|}{ One } & \multicolumn{3}{|c|}{ Two } & \multicolumn{3}{|c|}{ Three } & \multicolumn{3}{|c|}{ Four } & \multicolumn{3}{|c|}{ Five } \\
\hline & T) & WI & $\mathbb{N}$ & $\mathrm{T}$ & iI & $\mathbf{N}$ & $\mathrm{T}$ & V & $\bar{N}$ & TI & W & $\mathrm{N}$ & $T$ & W & $\bar{N}$ & $T$ & W & $\mathbf{N}$ \\
\hline Total & 28 & 18 & 10 & 4 & 1 & 3 & 8 & 7 & 1 & 8 & 6 & 2 & 4 & 3 & 1 & 4 & 2 & $\underline{2}$ \\
\hline $\begin{array}{l}\text { In home } \\
\text { Relatives } \\
\text { Non-reletives } \\
\text { Left alone }\end{array}$ & $\begin{array}{r}20 \\
11 \\
4 \\
5\end{array}$ & $\begin{array}{r}14 \\
6 \\
3 \\
5\end{array}$ & $\begin{array}{l}6 \\
5 \\
1 \\
0\end{array}$ & $\begin{array}{l}1 \\
0 \\
0 \\
1\end{array}$ & $\begin{array}{l}1 \\
0 \\
0 \\
1\end{array}$ & $\begin{array}{l}0 \\
0 \\
0 \\
0\end{array}$ & $\begin{array}{l}7 \\
4 \\
1 \\
2\end{array}$ & $\begin{array}{l}6 \\
3 \\
1 \\
2\end{array}$ & $\begin{array}{l}1 \\
1 \\
0 \\
0\end{array}$ & $\begin{array}{l}4 \\
1 \\
2 \\
1\end{array}$ & $\begin{array}{l}3 \\
1 \\
1 \\
1\end{array}$ & $\begin{array}{l}1 \\
0 \\
1 \\
0\end{array}$ & $\begin{array}{l}4 \\
2 \\
1 \\
1\end{array}$ & $\begin{array}{l}3 \\
1 \\
1 \\
1\end{array}$ & $\begin{array}{l}1 \\
1 \\
0 \\
0\end{array}$ & $\begin{array}{l}4 \\
4 \\
0 \\
0\end{array}$ & $\begin{array}{l}2 \\
2 \\
0 \\
0\end{array}$ & $\begin{array}{l}2 \\
2 \\
0 \\
0\end{array}$ \\
\hline $\begin{array}{l}\text { Outside home } \\
\text { organized social work } \\
\text { Placement } \\
\text { Day nursery } \\
\text { Relatives } \\
\text { Non-relatives }\end{array}$ & $\begin{array}{l}8 \\
4 \\
2 \\
2 \\
2 \\
2\end{array}$ & $\begin{array}{l}4 \\
2 \\
2 \\
0 \\
1 \\
1\end{array}$ & $\begin{array}{l}4 \\
2 \\
0 \\
2 \\
1 \\
1\end{array}$ & $\begin{array}{l}3 \\
1 \\
0 \\
1 \\
1 \\
1\end{array}$ & $\begin{array}{l}0 \\
0 \\
0 \\
0 \\
0 \\
0\end{array}$ & $\begin{array}{l}3 \\
1 \\
0 \\
1 \\
1 \\
1\end{array}$ & $\begin{array}{l}1 \\
0 \\
0 \\
0 \\
0 \\
1\end{array}$ & $\begin{array}{l}1 \\
0 \\
0 \\
0 \\
0 \\
1\end{array}$ & $\begin{array}{l}0 \\
0 \\
0 \\
0 \\
0 \\
0\end{array}$ & $\begin{array}{l}4 \\
3 \\
2 \\
1 \\
1 \\
0\end{array}$ & $\begin{array}{l}3 \\
2 \\
2 \\
0 \\
1 \\
0\end{array}$ & $\begin{array}{l}1 \\
1 \\
0 \\
1 \\
0 \\
0\end{array}$ & $\begin{array}{l}0 \\
0 \\
0 \\
0 \\
0 \\
0\end{array}$ & $\begin{array}{l}0 \\
0 \\
0 \\
0 \\
0 \\
0\end{array}$ & $\begin{array}{l}0 \\
0 \\
0 \\
0 \\
0 \\
0\end{array}$ & $\begin{array}{l}0 \\
0 \\
0 \\
0 \\
0 \\
0\end{array}$ & $\begin{array}{l}0 \\
0 \\
0 \\
0 \\
0 \\
0\end{array}$ & $\begin{array}{l}0 \\
0 \\
0 \\
0 \\
0 \\
0\end{array}$ \\
\hline
\end{tabular}


Table 24

TYPE OF CARE OF CHILDREN ACCORDING TO AGE OF MOTHER

\begin{tabular}{|c|c|c|c|c|c|c|c|c|c|c|c|c|c|c|c|c|c|c|c|c|c|c|c|c|}
\hline \multirow{3}{*}{$\begin{array}{l}\text { Type } \\
\text { of } \\
\text { Care }\end{array}$} & \multirow{2}{*}{\multicolumn{3}{|c|}{ Total }} & \multicolumn{21}{|c|}{ Age of Mother } \\
\hline & & & & \multicolumn{3}{|c|}{$16-20$} & \multicolumn{3}{|c|}{$21-25$} & \multicolumn{3}{|c|}{$26-30$} & \multicolumn{3}{|c|}{$31-35$} & \multicolumn{3}{|c|}{$36-40$} & \multicolumn{3}{|c|}{$41-45$} & \multicolumn{3}{|c|}{$46-50$} \\
\hline & $T$ & w & $\mathrm{N}$ & $T$ & 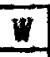 & $\mathbf{N}$ & $T$ & 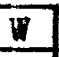 & $\mathbf{N}$ & $T$ & $W$ & $\mathrm{~N}$ & $T$ & 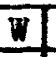 & $\mathrm{N}$ & $T$ & in & $\mathrm{N}$ & $T$ & $w$ & $\mathrm{~N}$ & $T$ & W & $\underline{N}$ \\
\hline Total & 28 & 18 & 10 & 1 & 1 & 0 & 4 & 1 & 3 & 3 & 3 & 0 & 8 & 5 & 3 & 6 & 5 & 1 & 4 & 2 & 2 & 2 & 1 & 1 \\
\hline $\begin{array}{l}\text { In home } \\
\text { Relatives } \\
\text { Non-relatives } \\
\text { Lert alone }\end{array}$ & $\begin{array}{r}20 \\
11 \\
4 \\
5\end{array}$ & $\begin{array}{r}14 \\
6 \\
3 \\
5\end{array}$ & $\begin{array}{l}6 \\
5 \\
1 \\
0\end{array}$ & $\begin{array}{l}0 \\
0 \\
0 \\
0\end{array}$ & $\begin{array}{l}0 \\
0 \\
0 \\
0\end{array}$ & $\begin{array}{l}0 \\
0 \\
0 \\
0\end{array}$ & $\begin{array}{l}1 \\
1 \\
0 \\
0\end{array}$ & $\begin{array}{l}1 \\
1 \\
0 \\
0\end{array}$ & $\begin{array}{l}0 \\
0 \\
0 \\
0\end{array}$ & $\begin{array}{l}1 \\
0 \\
0 \\
1\end{array}$ & $\begin{array}{l}1 \\
0 \\
0 \\
1\end{array}$ & $\begin{array}{l}0 \\
0 \\
0 \\
0\end{array}$ & $\begin{array}{l}8 \\
4 \\
3 \\
1\end{array}$ & $\begin{array}{l}5 \\
2 \\
2 \\
1\end{array}$ & $\begin{array}{l}3 \\
2 \\
1 \\
0\end{array}$ & $\begin{array}{l}6 \\
3 \\
1 \\
1\end{array}$ & $\begin{array}{l}5 \\
2 \\
1 \\
1\end{array}$ & $\begin{array}{l}1 \\
1 \\
0 \\
0\end{array}$ & $\begin{array}{l}4 \\
3 \\
0 \\
1\end{array}$ & $\begin{array}{l}2 \\
1 \\
0 \\
1\end{array}$ & $\begin{array}{l}2 \\
2 \\
0 \\
0\end{array}$ & $\begin{array}{l}1 \\
0 \\
0 \\
1\end{array}$ & $\begin{array}{l}1 \\
0 \\
0 \\
1\end{array}$ & $\begin{array}{l}0 \\
0 \\
0 \\
0\end{array}$ \\
\hline $\begin{array}{l}\text { Outside home } \\
\text { Organized social work } \\
\text { Placement } \\
\text { Day nursery } \\
\text { Relatives } \\
\text { Non-relatives }\end{array}$ & $\begin{array}{l}8 \\
4 \\
2 \\
2 \\
2 \\
2\end{array}$ & $\begin{array}{l}4 \\
2 \\
2 \\
0 \\
1 \\
1\end{array}$ & $\begin{array}{l}4 \\
2 \\
0 \\
2 \\
1 \\
1\end{array}$ & $\begin{array}{l}1 \\
1 \\
1 \\
0 \\
0 \\
0\end{array}$ & $\begin{array}{l}1 \\
1 \\
1 \\
0 \\
0 \\
0\end{array}$ & $\begin{array}{l}0 \\
0 \\
0 \\
0 \\
0 \\
0\end{array}$ & $\begin{array}{l}3 \\
2 \\
0 \\
2 \\
0 \\
1\end{array}$ & $\begin{array}{l}0 \\
0 \\
0 \\
0 \\
0 \\
0\end{array}$ & $\begin{array}{l}3 \\
2 \\
0 \\
2 \\
0 \\
1\end{array}$ & $\begin{array}{l}1 \\
1 \\
0 \\
0 \\
0 \\
1\end{array}$ & $\begin{array}{l}1 \\
1 \\
0 \\
0 \\
0 \\
1\end{array}$ & $\begin{array}{l}0 \\
0 \\
0 \\
0 \\
0 \\
0\end{array}$ & $\begin{array}{l}0 \\
0 \\
0 \\
0 \\
0 \\
0\end{array}$ & $\begin{array}{l}0 \\
0 \\
0 \\
0 \\
0 \\
0\end{array}$ & $\begin{array}{l}0 \\
0 \\
0 \\
0 \\
0 \\
0\end{array}$ & $\begin{array}{l}1 \\
0 \\
0 \\
0 \\
1 \\
0\end{array}$ & $\begin{array}{l}1 \\
0 \\
0 \\
0 \\
1 \\
0\end{array}$ & $\begin{array}{l}0 \\
0 \\
0 \\
0 \\
0 \\
0\end{array}$ & $\begin{array}{l}0 \\
0 \\
0 \\
0 \\
0 \\
0\end{array}$ & $\begin{array}{l}0 \\
0 \\
0 \\
0 \\
0 \\
0\end{array}$ & $\begin{array}{l}0 \\
0 \\
0 \\
0 \\
0 \\
0\end{array}$ & $\begin{array}{l}1 \\
0 \\
0 \\
0 \\
1 \\
0\end{array}$ & $\begin{array}{l}0 \\
0 \\
0 \\
0 \\
0 \\
0\end{array}$ & $\begin{array}{l}1 \\
0 \\
0 \\
0 \\
1 \\
0\end{array}$ \\
\hline
\end{tabular}


forty, three between forty-one and forty-five and one over forty-six did. The same is true about having a maid in the home to look after the children. None under thirty carried out this plan but four between thirty and forty did.

Information about the cost of care for the children both accordIng to the type of care given and the earnings of the mother, is given in Tables 25, 26 and 27. Seventeen of the twenty-eight pay nothing for the children's care. Twelve of these are relatives and in the other five, the chilaren are left alone. This plan for care by relatives is probably carried out because the mother feels that the children are better cared for by relatives. None of the Negroes pay relatives for caring for the children and only two of the white families do.

The amount of the mother's earnings seem to bave some effect on the amount pald for the children's care. In the seventeen where nothing was paid, the mother's earnings were between $\$ 4.00$ and $\$ 30.00$ per week. Within the group earning $\$ 20.00$ and over (ten), seven paid from $\$ 1.00$ to $\$ 7.00$ per week and three paid nothing. of those earning less than $\$ 20.00$ (eighteen), fourteen pald nothing and four pald from $60 \phi$ per child a week to $\$ 5.00$. Only four of the Negro families paid for care, the highest amount being paid was $\$ 2.00$ per week in contrast to $\$ 7.00$ per week for the white. Again the amount earned has to be taken into consideration, as the largest amount earned by a Negro was $\$ 18.00$ a week and by a white was $\$ 38.61$.

In trying to determine how adequate the care has been for the children, we found it very difficult to set up standards. Then, too, we found that individual cases might fit into more than one group. For 
Table 85

TYPE OF CARE OF CHILDREN ACCORDING TO WERKLY EARNINGS OF MOTHER

\begin{tabular}{|c|c|c|c|c|c|c|c|c|c|c|c|c|c|c|c|c|c|c|}
\hline \multirow{3}{*}{$\begin{array}{l}\text { Type } \\
\text { of } \\
\text { Care }\end{array}$} & \multirow{2}{*}{\multicolumn{3}{|c|}{ Total }} & \multicolumn{15}{|c|}{ Weekly Marnings of Mother } \\
\hline & & & & \multicolumn{3}{|c|}{$\begin{array}{l}\$ 0- \\
9.99\end{array}$} & \multicolumn{3}{|c|}{$\begin{array}{l}\$ 10- \\
14.99\end{array}$} & \multicolumn{3}{|c|}{$\begin{array}{l}\$ 15- \\
19.99\end{array}$} & \multicolumn{3}{|c|}{$\begin{array}{l}\$ 20- \\
24.99\end{array}$} & \multicolumn{3}{|c|}{$\begin{array}{l}\text { W25 \& } \\
\text { over }\end{array}$} \\
\hline & $T$ & $\mathbf{H}$ & $\mathbf{N}$ & $T$ & W & $\mathbf{N}$ & $\mathbf{T}$ & W & $\mathrm{N}$ & $T$ & II & $\mathrm{N}$ & $\mathrm{T}$ & W & $\mathrm{N}$ & $\mathrm{T}$ & W & $\mathrm{N}$ \\
\hline Total & 28 & 18 & 10 & 7 & 1 & 6 & 4 & 2 & 2 & 7 & 5 & 2 & 7 & 7 & 0 & 3 & 3 & 0 \\
\hline $\begin{array}{l}\text { In home } \\
\text { Relatives } \\
\text { Non-reletives } \\
\text { Left alone }\end{array}$ & $\begin{array}{r}20 \\
11 \\
4 \\
5\end{array}$ & $\begin{array}{r}14 \\
6 \\
3 \\
5\end{array}$ & $\begin{array}{l}6 \\
5 \\
1 \\
0\end{array}$ & $\begin{array}{l}4 \\
3 \\
0 \\
1\end{array}$ & $\begin{array}{l}1 \\
0 \\
0 \\
1\end{array}$ & $\begin{array}{l}3 \\
3 \\
0 \\
0\end{array}$ & $\begin{array}{l}4 \\
2 \\
1 \\
1\end{array}$ & $\begin{array}{l}2 \\
1 \\
0 \\
1\end{array}$ & $\begin{array}{l}2 \\
1 \\
1 \\
0\end{array}$ & $\begin{array}{l}6 \\
4 \\
0 \\
2\end{array}$ & $\begin{array}{l}5 \\
3 \\
0 \\
2\end{array}$ & $\begin{array}{l}1 \\
1 \\
0 \\
0\end{array}$ & $\begin{array}{l}4 \\
2 \\
2 \\
0\end{array}$ & $\begin{array}{l}4 \\
2 \\
2 \\
0\end{array}$ & $\begin{array}{l}0 \\
0 \\
0 \\
0\end{array}$ & $\begin{array}{l}2 \\
0 \\
1 \\
1\end{array}$ & $\begin{array}{l}2 \\
0 \\
1 \\
1\end{array}$ & $\begin{array}{l}0 \\
0 \\
0 \\
0\end{array}$ \\
\hline $\begin{array}{l}\text { Outside home } \\
\text { Organized social work } \\
\text { Placement } \\
\text { Day nursery } \\
\text { Relatives } \\
\text { Non-relatives }\end{array}$ & $\begin{array}{l}8 \\
4 \\
2 \\
2 \\
2 \\
2\end{array}$ & $\begin{array}{l}4 \\
2 \\
2 \\
0 \\
1 \\
1\end{array}$ & $\begin{array}{l}4 \\
2 \\
0 \\
2 \\
1 \\
1\end{array}$ & $\begin{array}{l}3 \\
1 \\
0 \\
1 \\
1 \\
1\end{array}$ & $\begin{array}{l}0 \\
0 \\
0 \\
0 \\
0 \\
0\end{array}$ & $\begin{array}{l}3 \\
1 \\
0 \\
1 \\
1 \\
1\end{array}$ & $\begin{array}{l}0 \\
0 \\
0 \\
0 \\
0 \\
0\end{array}$ & $\begin{array}{l}0 \\
0 \\
0 \\
0 \\
0 \\
0\end{array}$ & $\begin{array}{l}0 \\
0 \\
0 \\
0 \\
0 \\
0\end{array}$ & $\begin{array}{l}1 \\
1 \\
0 \\
1 \\
0 \\
0\end{array}$ & $\begin{array}{l}0 \\
0 \\
0 \\
0 \\
0 \\
0\end{array}$ & $\begin{array}{l}1 \\
1 \\
0 \\
1 \\
0 \\
0\end{array}$ & $\begin{array}{l}3 \\
2 \\
2 \\
0 \\
0 \\
1\end{array}$ & $\begin{array}{l}3 \\
2 \\
2 \\
0 \\
0 \\
1\end{array}$ & $\begin{array}{l}0 \\
0 \\
0 \\
0 \\
0 \\
0\end{array}$ & $\begin{array}{l}1 \\
0 \\
0 \\
0 \\
1 \\
0\end{array}$ & $\begin{array}{l}1 \\
0 \\
0 \\
0 \\
1 \\
0\end{array} \mid$ & $\begin{array}{l}0 \\
0 \\
0 \\
0 \\
0 \\
0\end{array}$ \\
\hline
\end{tabular}


Table 26

TYPE OF CARE OF CEILDREN ACCORDING TO WEEKLY COST OF CARD

\begin{tabular}{|c|c|c|c|c|c|c|c|c|c|c|c|c|c|c|c|c|c|}
\hline \multirow{3}{*}{$\begin{array}{l}\text { Type } \\
\text { of } \\
\text { Care }\end{array}$} & \multicolumn{17}{|c|}{ Week1y Cost of Care } \\
\hline & \multicolumn{3}{|c|}{ Total } & \multicolumn{3}{|c|}{ Nothing } & \multicolumn{3}{|c|}{$\begin{array}{c}60 \not \\
\text { per wk }\end{array}$} & \multicolumn{3}{|c|}{$\begin{array}{l}\$ 1- \\
3.99\end{array}$} & \multicolumn{3}{|c|}{$\begin{array}{l}\$ 4- \\
6.99\end{array}$} & \multicolumn{2}{|c|}{$\begin{array}{l}\$ 7 \& \\
\text { over }\end{array}$} \\
\hline & $\mathrm{T}$ & in & $\mathrm{N}$ & $\mathbf{T}$ & III & $N$ & $\mathbf{T}$ & D & $\mathrm{N}$ & $T$ & $\boldsymbol{W}$ & $\mathrm{N}$ & $T$ & $\nabla$ & $\mathrm{N}$ & $T$ & D \\
\hline Total & 28 & 18 & 10 & 17 & 11 & 6 & 2 & 0 & 2 & 4 & 2 & 2 & 3 & 3 & 0 & 2 & 2 \\
\hline In home & 20 & 14 & 6 & 15 & 10 & 5 & 0 & 0 & 0 & 2 & 1 & 1 & 2 & 2 & 0 & 1 & 1 \\
\hline Relatives & 11 & 6 & 5 & 10 & 5 & 5 & 0 & 0 & 0 & 1 & 1 & 0 & 0 & 0 & 0 & 0 & 0 \\
\hline Non-relatives & 4 & 3 & 1 & 0 & 0 & 0 & 0 & 0 & 0 & 1 & 0 & 1 & 2 & 2 & 0 & 1 & 1 \\
\hline Left alone & 5 & 5 & 0 & 5 & 5 & 0 & 0 & 0 & 0 & 0 & 0 & 0 & 0 & 0 & 0 & 0 & 0 \\
\hline Outside home & 8 & 4 & 4 & 2 & 1 & 1 & 2 & 0 & 2 & 2 & 1 & 1 & 1 & 1 & 0 & 1 & 1 \\
\hline organized social work & 3 & 1 & 2 & 0 & 0 & 0 & 2 & 0 & 2 & 1 & 1 & 0 & 0 & 0 & 0 & 0 & 0 \\
\hline Placement & 1 & 1 & 0 & 0 & 0 & 0 & 0 & 0 & 0 & 1 & 1 & 0 & 0 & 0 & 0 & 0 & 0 \\
\hline Day nursery & 2 & 0 & 2 & 0 & 0 & 0 & 2 & 0 & 2 & 0 & 0 & 0 & 0 & 0 & 0 & 0 & 0 \\
\hline Relatives & 3 & 2 & 1 & 2 & 1 & 1 & 0 & 0 & 0 & 0 & 0 & 0 & 1 & 1 & 0 & 0 & 0 \\
\hline Non-relatives & 2 & 1 & 1 & 0 & 0 & 0 & 0 & 0 & 0 & 1 & 0 & 1 & 0 & 0 & 0 & 1 & 1 \\
\hline
\end{tabular}


Table 27

WEEKLY COST OF CARE FOR CHILDREN ACCORDING TO WERKIY EARNINGS OF MOTHER

\begin{tabular}{|c|c|c|c|c|c|c|c|c|c|c|c|c|c|c|c|c|c|c|}
\hline \multirow{3}{*}{$\begin{array}{c}\text { Cost } \\
\text { of } \\
\text { care }\end{array}$} & \multicolumn{18}{|c|}{ Earnings of Mother } \\
\hline & \multicolumn{3}{|c|}{ Total } & \multicolumn{3}{|c|}{$\begin{array}{l}\$ 0- \\
9.99\end{array}$} & \multicolumn{3}{|c|}{$\begin{array}{l}\$ 10- \\
14.99\end{array}$} & \multicolumn{3}{|c|}{$\begin{array}{l}\$ 15- \\
19.99\end{array}$} & \multicolumn{3}{|c|}{$\begin{array}{l}20- \\
24.99\end{array}$} & \multicolumn{3}{|c|}{$\begin{array}{l}\$ 25 \& \\
\text { over }\end{array}$} \\
\hline & $T$ & DI & $\mathrm{N}$ & $\mathbf{T}$ & 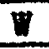 & $\mathrm{N}$ & $T$ & $W$ & $\mathrm{~N}$ & $\mathbf{T}$ & $\mathbf{W}$ & $\mathbf{N}$ & $\mathrm{T}$ & $W$ & $\mathrm{~N}$ & $T$ & $W$ & $\mathbf{N}$ \\
\hline Total & 28 & 18 & 10 & 7 & 1 & 6 & 4 & 2 & 2 & 7 & 5 & 2 & 7 & 7 & 0 & 3 & 3 & 0 \\
\hline Nothing & 17 & 11 & 6 & 5 & 1 & 4 & 3 & 2 & 1 & 6 & 5 & 1 & 1 & 1 & 0 & 2 & 2 & 0 \\
\hline $50 \not$ per wh per child & 2 & 0 & 2 & 1 & 0 & 1 & 0 & 0 & 0 & 1 & 0 & 1 & 0 & 0 & 0 & 0 & 0 & 0 \\
\hline \$1. -3.99 per weอk & 4 & 2 & 2 & 1 & 0 & 1 & 1 & 0 & 1 & 0 & 0 & 0 & 2 & 2 & 0 & 0 & 0 & 0 \\
\hline$\$ 4 .-6.99 n$ & 3 & 3 & 0 & 0 & 0 & 0 & 0 & 0 & 0 & 0 & 0 & 0 & 3 & 3 & 0 & 0 & 0 & 0 \\
\hline$\$ 7 . \&$ over " & 2 & 2 & 0 & 0 & 0 & 0 & 0 & 0 & 0 & 0 & 0 & 0 & 1 & 1 & 0 & 1 & 1 & 0 \\
\hline
\end{tabular}


example, a seventeen year old girl who looked af ter three younger children might be considered a relative caring for the children. She might also be considered in the group of children left alone. Where the care seemed adequate and there was no evidence of neglect, it was counted with relatives. Where there was evidence of neglect, it was counted as the children being left alone. The following gives more information about the relatives who cared for the children as well as the number and ages of children under their care.

$$
\text { Table } 28
$$

NUMBER \& AGES OF CHILDREN ACCORDING TO AGE OF RELATIVE CARING FOR THEM.

\begin{tabular}{|c|c|c|c|}
\hline $\begin{array}{c}\text { Relative's } \\
\text { Age }\end{array}$ & Relationship & $\begin{array}{l}\text { Number of } \\
\text { Children }\end{array}$ & $\begin{array}{l}\text { Ages of } \\
\text { Chilaren }\end{array}$ \\
\hline $\begin{array}{l}60 \\
60 \\
41 \text { (i11) } \\
39 \text { (111) } \\
18 \\
17 \\
16 \\
65 \\
65 \\
\text { Adu1t } \\
21 \\
19 \\
17\end{array}$ & $\begin{array}{l}\text { Grandmother } \\
\text { Father } \\
\text { Brother } \\
\text { Sister } \\
\text { Aunt } \\
\text { Grandmother (colored) } \\
\text { Aunt " } \\
\text { Sister } \\
\text { Mother }\end{array}$ & $\begin{array}{l}1 \\
3 \\
2 \\
4 \\
2 \\
3 \\
2 \\
5 \\
4 \\
1 \\
9 \\
6 \\
1\end{array}$ & $\begin{array}{c}3 \\
16-9-7 \\
18-16 \\
14-13-11-10 \\
12-10 \\
15-12-10 \\
3 \text { yrs. }-9 \text { months } \\
21-20-17-17-1 \\
17-14-15-6 \\
6 \\
17-12-10-8-4-3-2-1 \\
17-15-10-8-6-1 \\
7 \text { months }\end{array}$ \\
\hline
\end{tabular}

or this group cared for by relatives, it seems that several cases are questionable. Thirteen of the children cared for by relatives in the home have had some difficulty. 
In these families where relatives look after the child, the supervision of seven (four white, three Negro) seems to be adequate, and six (three white, three Negro) questionab1e.

There is a question, too, about the adequacy of the maids hired. Very 11ttle was known by the mothers about the neighbors who looked after the children. The selection seems to have been made on the basis that they were close to home rather than on how well they could care for the children.

of the children who were left alone, only one of these might be considered adequately looked after. 4

In summarizing the number of families where chilaren seemed adequately cared for, one certainly gets the impression that much is needed to make this a favorable picture as half of the children are not proper1y supervised. Only four of the Negro families were in this group of improperly supervised. This means that ten of eighteen of the white families were not adequately cared for in contrast to four of ten of the Negroes.

What were the results of this lack of supervision? Are there tangible things which we might be able to see? We think there are several places where we can see the effect of this lack of supervision.

${ }^{4}$ This child was fifteen years of age and was working in the afternoons. The other four families where the children were left alone were as follows: three children in one family, oldest eleven years, left from 5:00 p.m., to 2:00 a.m., in a rooming house, two children in one family, oldest eleven, left to go to clubs or roam the streets in the afternoon, two children in one family, ages fifteen and thirteen. showing beginning delinquent behavior, and four children in the other family ages sixteen, fourteen, twelve and one, left without supervision twenty hours a day with the oldest child assuming responsibility for the care of the family. 
First, there is the school adjustment. Nineteen of the fifty school children are retarded in their school work. Fifteen of these are behind only one grade. Four are more than a grade behind. Table 29

NUMBER OF YEARS SCHOOL RETARDATION ACCORDING TO RACE

Total White Negro

$\begin{array}{lrrr}\text { One year } & 15 & 10 & 5 \\ \text { Two years } & 2 & 1 & 1 \\ \text { Three " } & \frac{2}{19} & \frac{1}{12} & \frac{1}{7}\end{array}$

Twelve out of thirty-two white children are a year or more behind and seven out of eighteen Negro children are behind according to information secured from the parents. The mothers reported that four children are having difficulty at school---either poor grades, or inability to get along with the teacher or other children.

The information regarding the children's school adjustment was checked with the school for the purpose of verifying information and of securing additional data about the child's adjustment. It was not possible to secure this information on fourteen children due to the family's feeling about other people knowing of their contact with Family Service Organization. The data regarding grade which was secured from the mother was the same except in one case. Of these thirty-six chilaren, eleven repeated one semester or work and four repeated two or more semesters. This material must be evaluated as not all of the children had attended the Louisville Public Schools during their school life. It was not possible to check on information regarding previous attendance at 
schools outside the city.

The average scholarship for this group during the fall term of 1942 was two or average.

$$
\begin{aligned}
& \text { Table } 30 \\
& \text { SCHOLARSHIP OF CHILDREN } \\
& \text { Grade No. of children } \\
& \text { 1.... Above Average..... } 4 \\
& \text { 2.....Average.........28 } \\
& \text { 3....Failing........4 }
\end{aligned}
$$

It was not possible to secure material regarding the native ability of these children as recorded through intelligence tests as few had been given Individual tests. According to scholarship these children do not indicate any difference between themselves and other children where the mother is at home looking after her family.

Absence from school was quite a problem. Only five of the children missed no time during the fell semester.

Table 31

NUMBER OF DAYS' ABSENCE FROM SCHOOL

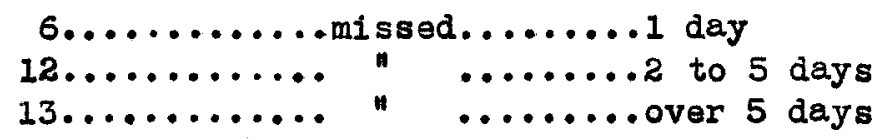

The average absence in the Louisville Public School System for this semester was 9.7 days while the average for this group was 7.35 days. The most frequent reason for absence was iliness (159 days). Others indicated by the school were poverty and bad weather. The ract that the school did not know the reason for the child's absence for a total of eighty-nine days seems unusual. This is more than one-third of the total absence (265 days). Perhaps the teacher made inquiry but failed to keep 
a record of this. However, It would seem logical for the school to make more effort to check on each day's absence from school.

There seems no correlation between the number of days absent and the scholarship average. Only one child was absent a great deal and was failing. There also seems no connection between absence and health as only three children are not considered in good health. One of these is crippled, one has rhoumatic fever, and the other needs dental care.

There was little indication in the school records that these children were considered difficult in any way. Only one child was in a special class. A fow talked a great deal, had poor work habits, or disturbed the class. Most (twenty-three) had no trouble at school. The picture shown by Family Service Organization's records is quite different. Eight children have some physical difficulty. This ranged from needed tonsilectomy, rheumatic heart disease, to poor physical development.

In our opinion, the most serious trouble in the entire picture is the emotional difficulties of the children concerned. Twenty of the eighty-seven children had some sort of difficulty which had been discussed with the caseworker. Some of these were serious and some not so difficult. Four had more than one difficulty.

$$
\text { Table } 32
$$

PROBLEBUSS OF CHILDREAN

Sex problems........4 4

Trouble at school.... 4

Running away from home 2

Behavior problem...... 2

"Hard to manage"..... 2

Thumb sucking........2

Feebleminded......... 2

Miscellaneous........... $\frac{6}{24}$ 
of the ten children who were out of the home (not included in the eighty-seven) three were placed out of the home because they could not adjust within the home environment.

Looking at the entire picture of children in homes where the mother works, it would seem that any advantage in earning the living is lost in other forms of maladjustment. We have been able to find no comparable studies of the effect upon the children of the mothers' working. However, we must again note that this is a very small group of families and that these are families with serious enough troubles to ask a soclal agency for belp. The material on emotional problems comes mostly from the case record and probably could not be secured through interviews. It is distressing that the children must suffer from lack of attention. At the same time, we recognize that the mother wth her many other tasks, can give only a small portion of the guidance necessary and that this task of supervision is pushed intothe background when other physical wants such as cooking, washing, et cotera must be cared for. 
CEAPTER IV

CASE WORK TREATMENT 


\section{Chapter IV}

\section{Case Work Treatment}

We have discussed in previous chapters the problems which we felt these mothers were facing. What problems do the mothers recognize? With what problems do they want help? When asked "What is your biggest problem?", most of the mothers felt that insufficient money was the root of their troubles. One would certainly agree that these mothers worked from necessity and not for pin money as is the popular conception. 1

The problems which the mothers presented when interview by a caseworker indicated a wide scope of difficulties. These varied from need for relief to a request for help with legal problems. While the problems of twelve of them were connected with the mothers employment, most came to the agency for help with other types of trouble. We were interested in knowing whether part of the casework treatment was connected with the mothers work. With this in mind, the following questions were considered whon reading the case records:

1. Was any guidance given in securing employment?

2. Was the mother helped in getting or holding a job by the encouragenent of the worker? Did the caseworker understand the mothers' problems in connection with her employment and help her solve them? Th1s was considered bolstering of morale.

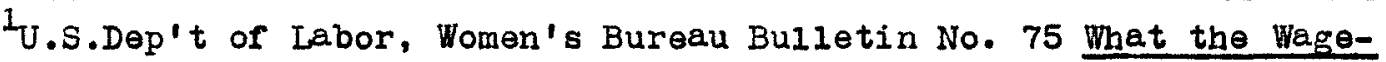
Earning Woman Contributes to Family Support (Washington: Government Printing office, 1929) p. 1 
3. Was help given in arranging care for children?

4. Was help given in planning housework?

5. Was budgeting service given?

6. Was the mother helped to secure medical care?

The answer to these questions are given in Table 33 and we note that with the exception of planning the housework that this was a part of treatment as more than half were helped.

Table 33

CASE WORK TREATMENT OF WORKING MOTAERS

UNDER THE CARE OF FAllIIY SERVICE

ORGANIZATION OF LOUISVILLE, KBNTUCKY.

\begin{tabular}{l|c}
\hline & \\
\hline Treatment & 15 \\
Help in securing employment & 21 \\
Bolstering of morale & 15 \\
Help in caring for child & 5 \\
Help in arranging housework & 21 \\
Budgeting Service & 15 \\
Help in getting medical care & \\
\hline
\end{tabular}

What were the other problems that brought these mothers to Family Service Organization? As one can readily realize from the small wages of most of these mothers, the need for relief played a largo part in bringing them to make application for help. One can also see very clearly the marital difficulties of these families if we just glance at the figures showing the marital status of the mothers. 
These two plus the difficulties of rearing children and the needed personality adjustments of the mothers were of great concern as noted on the applications. Mention should be made here that twelve of these applications were made by the client himself and sixteen were referred by other people. Few (7) had been known to Family Service Organization before. Treatment required a varying amount of time and, of course, was based upon individual needs. As all of these cases were active on the date they were studied, treatment had not been completed. The length of time for the present contact with the family varied from one month to more than two years. Treatment varied from the giving of relief and helping in budgeting income to marriage counseling and general supportive care.

Most of the mothers indicated that they were satisfied with the plans which the caseworker had helped them arrange. Four indicated that they were not; three of these wanted relief and felt that the caseworker had not taken into consideration 211 the factors of the situation.

In this chapter we have attempted to summarize the plan of treatment which was followed by the caseworker of Family Service organization. In all but two areas we feel that progress has been made and that the plans, which were followed, achieved the goals for which the clients and caseworkers had striven. In the two areas, household planning and care of children, which we feel were less successful, there seems a need for more concentration on the part of both caseworker and client. Through this concentrating on the household work some better arrangement might be made. The question of the care of the children is much more 
difficult. This involves not only the community resouroes for care of children but also the financial status of the family. There are few resources for the day care of white chlldren in Louisvilie. A survey of these and the need for additional facilities is being conducted now and there is the possiblifty that federal funds will be available to provide this kind of care. However, there still remains the question of what arrangements would be made for older children both white and Negro. Perhaps the community centers could develop programs which would fill this gap. It would need to be a continuing plan and not like that arranged by the mother of the two boys, age ten and eleven, who now go to clubs in the afternoon. Certainly, now, with so many women going to work, is the time when careful consideration should be given to plans for the children. 
CEAPTER V

CONCLUSIONS 


\section{Chapter V}

Conclusions

There are several things which are of significance in this study. First, these mothers work not because they want to, but because it is necessary for them to do so. This is true, too, of the average woman who earns her living. Thls being the case it would seem loglcal that more emphasis should be placed on the training of women so that they would be better prepared to earn their living and properly care for bome and children at the same time.

Second, the women studied certainly did not have the opportunity to earn enough to take care of themselves and their children. However, these women earned as much as their contemporaries in other cities. The raot that so large a portion were forced into domestic and personal service is probably traceable to their lack of training. Only one of the entire group had a high school education. There seems more possibility that the woman's status as homemaker is being recognized as a contributing occupation since Sir Hiliam Beveridge's report on Social security for England has been published. 1

Third, this same situation i. e. lack of training, is being repeated in the next generation. As you will recall most of the children of sixteen and over had dropped out of school and had gone to work. Considering this and the fact that so many of the children were unable to keep up in school with children their own age, it is evident that these children are not being adequately prepared to enter the business world.

Beveridge, Sir Miliam, Social Insurance \& Allied Services (New York : Macmilian Co. 1942) 
Fourth, Industry or manufacturing seems to offer more opportunities and higher wages than any of the other classifications. However, general business conditions and the influx of defense industries into the Louisville area have altered this picture in the last few months. Considering the changes in employment due to the war situation, there will be many more women entering the labor market in the next few months. This will, of course, add to the number of children needing care. Fifth, the mothers' wages are spent almost entirely on the family. We do not have information on the portion of the fathers' income which he contributed but we do know the amount contributed. As we know from other studies that men's wages are higher than women's and as we can compare the wages of the mother with the contribution of the father, we recognize that the mother's contribution and acceptance of responsibility are greater than the father. This indicates a greater sense of responsibility on the part of the women. Perhaps there should be more emphasis in the earlier trainIng of men in developing a sense of responsibility to the family. Sixth, in addition to the mother's financial contribution to the family, there is the contribution of her work in keeping the house clean, in cooking, washing, ironing, et cetera. The hours spent in performing household tasks after putting in a long day at work indicated something of the sacrifice which the mother makes.

Seventh, this crowding of all other activities into a few short hours makes it practically impossible for the mother to take care of the responsibilities which she has. There is 1ittle opportunity to play with the children, to hear their confidences, or to try to understand their problems. It is not surprising to note that the children are neglected in 
so many of these homes. One would say that the mother is missing one of the most interesting parts of the rearing of her children. Considering the small amount of time she has and the numerous tasks which are pushIng to be done, she cannot be blamed for omitting the things which are 1ess obvious.

Gighth, notation must be made that the majority of the families in this study were broken homes. This breaking of family ties has, natura11y, been one of the causes of the emotional difficulties of the chilaren. However, part of this seems also due to the mother's lack of time for her children. No matter how great her interest in her children, there are only twenty-four hours in a day and with so much time spent In earning the living and doing the housework, she cannot have either the time or the energy to deal constructively with the children's troubles. Because of this she must depend upon someone else to do this for her or let it go undone unless she is a vary unusual mother.

Ninth and most important, this care which is provided for the most part by relatives as the majority of these children are cared for by relatives in their own home has proven inadequate. Many of the children are uneble to keep up with their school work, there are frequent absences from school, and the children exhibit emotional difficulties. The care provided by maids and neighbors is insufficient also. It is especially distressing to see these children who are left without any cere or supervision.

These mothers are unable to pay for the care needed by their children. A few have made an effort to meet this problem through hired help but this was not successful. Some would be able to pay a sma1l amount 
for care and some would not. In thinking about arranging for better care for them, some plan must be made to meet the necessary expenses for this care in some manner other than the present one. To try to remedy this situation--inadequate care for chiloren of working mothers--we need to set up standards for care of children which will safeguard them. We may not be able to do this in a positive manner from the data on hand, but it does point out certain negative features which should be considered.

1. Children of eighteen years and under do not have sufficient judgment to $100 k$ after themselves and to care for younger children. They should not be left alone.

2. Fathers who are ill or crippled do not provide adequate supervision for the children.

3. Maids, unless carefully selected and supervised, do not assume the necessary responsibility for the care of children. 4. Maids should not be less than eighteen years of age. 5. If neighbors are supervising children, much care should be exercised in selecting them. This should be done on the basis of ability to care for the child rather than proximity to the home. Having set up certain standards, there is next the question of putting them into practice. The caseworker needs to be more aware of how adequate the care of the children is as well as how the plan can be improved. Most of these mothers will welcome a discussion of the children and the problems which they present. Through this discussion perhaps a better plan may be worked out. On the other hand, we need more resources in our community such as day nurseries so that the caseworker can recommend a plan that is 
adequate. The older children might be cared for more effectively as has been suggested before by community centers. There should be some type of program for these children that will care for them after school hours. There might also be a register of approved housekeepers that would be available in homes where other plans were not feasible. Perhaps the women who have been working as Horks Progress Administration housekeepers and are now or soon will be wi thout employment could be used in this manner. An expanded housekeeping service for Family Service Organization might also

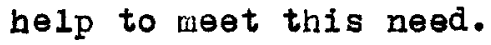

The Family Service Organization housekeeping service (which is mostly teaching and demonstrating) could be used to advantage in helping the mother plan to perform her household tasks in the least possible time. This, with the planning of the caseworker, might help the mother arrange these tasks more advantageously and then she would have more time for the children.

The other type of housekeeping service would be a listing of available capable housekeepers where the family could secure information and then make their own arrangements. This would be helpful where the mother works at night and cannot be at home with the children.

Foster day care for the children might also be used.

Time and affection with security should bring about miraculous changes in the behavior of the children. We do not have any magic wand to create the affection and security needed by the children, but feel that time plus sufficient energy and interest on the part of the mother will help to encourage or create this. We recognize that the working mother has many tasks and responsibilities and that one more will be hard to 
assume, but any plan which will improve the welfare of the children is worth the necessary time and effort. 
APPENDIX 
Members of household: Relationship Physical Condition Mental Condition

Name of father and mother:

Ages Race

Address:

Marital status:

Date of marriage

Employment of father: Occupational classification Other skills

Earnings Contribution By court order

Work record for regularity of employment

Hours of employment if home Whereabouts if not

Education

Defense industry

Time lost during last month

Reason

If not employed, why not?

Employment of mother: ocoupational classification other skills

Farnings Contribution Defense industry

Work record for regularity of employment

Hours of employment Overtime Bonus Fines

Bducation Age at which started work

Work prior to marriage? How long?

When did mother seek employment after marriage? Interruptions?

Why did mother seek employment after marriage?

Time lost from work during last month Reason

Length of time required going to and from work 
Children at home: Ages Grade Emplayment EArnings Contributions

Children out of home who are contributing:
Married or single Whereabouts Earnings Contributions

Behavior problems of children: Truancy Delinquency Poor Grades

Care of children: At home outside home

Nursery

If not in nursery: Age of person in charge Hours of employment

Duties other than care of children

Cost of care?

Is mother satisfied with care?

What other plan has been tried?

Does caseworker consider care adequate?

Care of housework: (Please put in hours which work is done after question)

Who does washing?

Cooking Ironing

Marketing? Clearing away?

Repairing of clothing? Cleaning? Special cleaning?

Clothing purchased readymade? Made at home?

Baking?

Care of fires?

Household planning or supervision?

Housing: No. of rooms Rent own Length of time at present address Other members of household: Relationship Contribution 
Treatment:

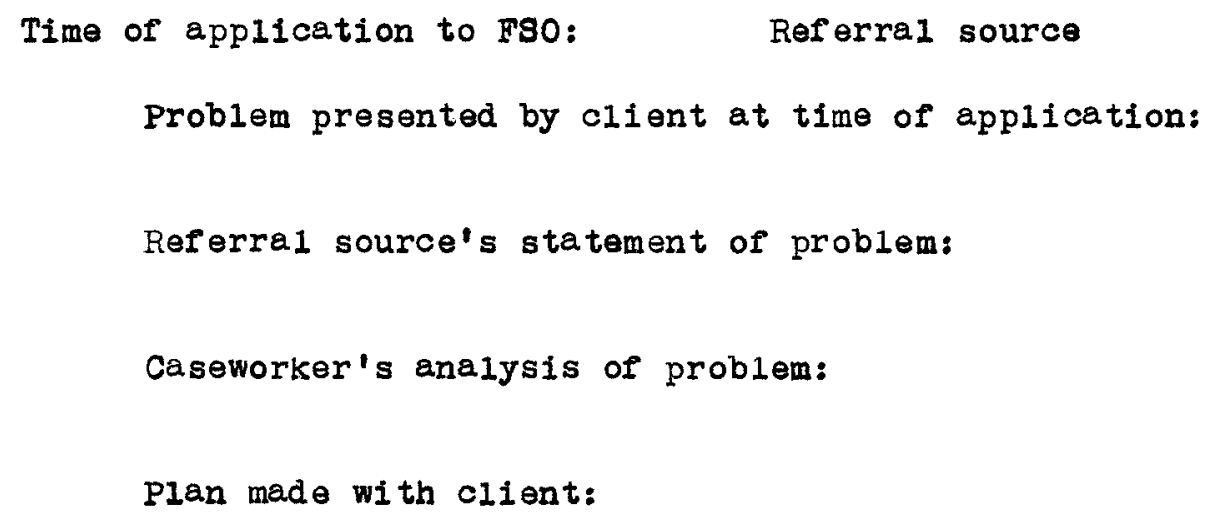

Treatment plans being carried out or which have been carried out during contact: 
Treatment in connection with employment of mother:

Helping to find employment:

Bolstering of morale:

Helpling arrange for care of children:

Helping arrange for care of housework:

Budgeting services:

Medical care:

Misc. State

What service does mother feel FSO has given or is giving?

Is she satisfied with the plan?

$\operatorname{ssX}$ 
SCHEDULE FOR SCHOOL INFORMATION

Name

Age

Sex

Grade

Grades repeated

Attendance - no. of days absent during fall term

Reason for absence

Average Scholarship

Behavior problem

Health

I. Q. 
BIBLIOGRAPEY 


\section{Public Documents}

U. S. Department of Labor, Women's Bureau Bulletin No. Washington: Government Printing office,

\begin{tabular}{|c|c|c|}
\hline No. & Tit1e & Published \\
\hline 23 & Family Status of Breadwinning Women & 1922 \\
\hline 29 & Women in Ky. Industries & 1921 \\
\hline 30 & $\begin{array}{l}\text { Share of Wage Rarning Women in } \\
\text { Family Support }\end{array}$ & 1923 \\
\hline 49 & $\begin{array}{l}\text { Women Workers \& Family support } \\
\text { Study made by students in the Economics } \\
\text { course at the Bryn Hawr Summer School, } \\
\text { under the direction of Prof. Amy Hewes }\end{array}$ & 1925 \\
\hline 75 & $\begin{array}{l}\text { What the Wage Barning Women Contributes } \\
\text { to Family Support, by Agnes I. Peterson }\end{array}$ & 1929 \\
\hline 84 & Fact Finding with the Women's Bureau & 1930 \\
\hline 155 & $\frac{\text { Women in the Economy of the U. S. of }}{\text { America, by Mary Elizabeth Pigeon }}$ & 1937 \\
\hline 168 & $\begin{array}{l}\text { Employed Women \& Family support } \\
\text { by Margaret Thompson Mettert \& } \\
\text { Mary Blizabeth P1geon }\end{array}$ & 1939 \\
\hline 172 & $\begin{array}{l}\text { The Women Wage Barner - Ber Situation } \\
\text { Today, by Bliabeth D. Benham }\end{array}$ & 1939 \\
\hline 31 & $\begin{array}{l}\text { The Non-Working Time of Industrial } \\
\text { Women Workers - Study by students } \\
\text { of the Hudson Shore Labor Sohool under } \\
\text { the direction of Juliet Flsher }\end{array}$ & 1940 \\
\hline
\end{tabular}


U. S. Department of Labor, Children's Bureau. Children in Wartime. No. 3 - Bureau Publication No. 284 Standards for Day Care of Working Mothers 1942

U. S. Department of Labor, Children's Bureau - Defense of Children, series No. 2

Children Bear the Promise of a Better World 1943

Reports

Beveridge, Sir William, Social Insurance \& Allied Services New York: Macmilian Company, 1942

\section{Magazine Articles}

Child Welfare League of America - Bulletin- Vol. XXI- No.9 November, 1942

War Time Influences on Juvenile Delinquency,

by Alice Scott Nutt - p. 1-14

Casework Service to a Day Nursery, by Eleanor P. Sheldon

Labor Information Bulletin - U. S. Dep't of Labor - Aug. 1942

Survey Shows How Women War Workers Live Manpower Policy as to Working Mothera p. 6-7 Women's Place in Var Labor Force $\quad$ p. 7-8 Best Practice for Women War Workers $\quad$ p. 8-9 Women's Work Hours in Brit1sh War $\quad$ p. 9 Industries

\section{Pamphlets}

Child Welfare League of America

Help Mothers Win the War, by Ethel S. Bur - 1942 Counciling Service in a Day Care Program, by Emma S. Lundberg 1942

War Manpower Commlssion - Policy on Employment in Industry of Women with Young Children August 12, 1942

Office of Defense Health \& Welfare Services Day Care Program of the Federal Government Ju1y 27, 1942 
Unpub11shed Mater1a1

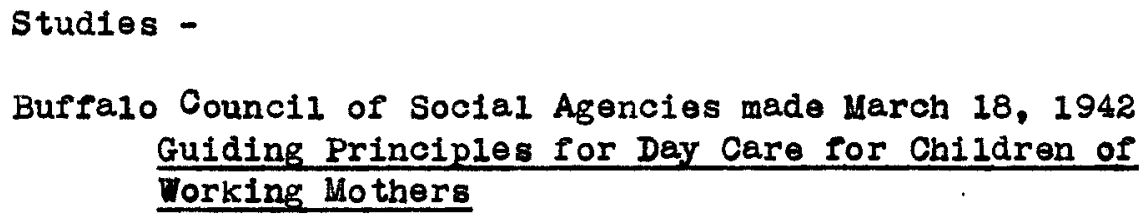
Guiding Principles for Day Care for Children of Working Mothers

Minneapolis Defense Council, made May 18, 1942

Care of Children of Morking Mothers

St. Paul, Minn., made Ju1y 24, 1942

Belleville, N. J., made 1942

Preliminary Report of Community Service Bureau

* Material secured thru Family Welfare Association or America 